\title{
Indumentária e moda: seleção bibliográfica em português
}

Adilson José de Almeida

Museu Paulista/Universidade de São Paulo

O texto que ora apresentamos constitui parte de um levantamento mais amplo sobre indumentária e moda. Elaboramos, no momento, uma listagem comentada de livros publicados em língua portuguesa (originais ou traduzidos) no período de 1979/1996. Embora este critério (apenas títulos em português) possa parecer arbitrário ele tem sua utilidade: permite dispormos de um referencial básico para uso imediato tanto científico, como informativo ou de divulgação (fornecemos inclusive a localização dos textos); possibilita também uma caracterização inicial do campo editorial entre nós, observando-se os interesses, temas e enfoques dominantes. Tratamos nesta oportunidade apenas de livros (ou capítulos de livros) não incluindo artigos, folhetos, dissertações e teses. O recorte cronológico mostrou-se recomendável pois naquele período intensificaram-se as publicações no campo do qual nos ocupamos.

Podemos observar um nítido interesse pelas roupas de moda e pouca atenção se dá a outros tipos de vestuário como as roupas de trabalho ou uniformes. Em função deste predomínio a circulação e o consumo são as áreas mais abordadas nos textos, marginalizando-se, por exemplo, os problemas referentes à produção de roupas.

A história do vestuário é, de longe, o domínio mais contemplado, tendo um peso significativo as publicações comemorativas patrocinadas por empresas do setor (importantes por organizarem informações relativas a certos temas e objetos - peças de indumentária como camisetas e calçados já foram explorados neste tipo de publicação). Num domínio correlato, a biografia, e 
também em relação a obras de referência, tais como guias e glossários, podemos observar que existe interesse embora a quantidade de títulos seja pequena em comparação àquele primeiro domínio.

Em outras áreas os estudos já escasseiam, pouco existindo sobre sociologia, psicologia, antropologia e semiologia da moda, embora, como veremos, em todas tenhamos algumas pesquisas importantes publicadas. Estudos temáticos são bem poucos ainda, encontramos apenas um catálogo para moda infantil e uma análise sobre jornalismo de moda. Observemos, ainda, que a grande maioria destas publicações são obras de divulgação, não voltadas para a produção de conhecimento novo.

A listagem mais adiante apresentada procura caracterizar as obras de forma mais descritiva do que analítica. No entanto, para dar uma idéia mais precisa da natureza do conhecimento disponível, fizemos preceder a listagem propriamente dita por um tratamento mais amplo de obras que marcam padrões de análise, não por constituirem modelos a serem copiados mas por indicarem os cuidados básicos para estudos mais aprofundados. Em análise estrutural temos o já clássico estudo semiológico de Roland Barthes sobre descrições texłuais de roupas de moda e o trabalho de Marshall Sahlins que, embora não tendo a mesma amplitude, procura fixar os princípios e cuidados metodológicos gerais para o desenvolvimento deste lipo de abordagem. A pesquisa histórica conta com dois trabalhos importantes, Império do efêmero de Lipovetsky que examina as relações entre o fenônemo da moda e valores específicos das sociedades modernas e Espírito das roupas de Gilda de Mello e Souza, a primeira tentativa de análise sistemática empreendida entre nós, desenvolvendo o debate que relaciona moda e costume. Por fim, a pesquisa sociológica de Alice Rangel de Abreu sobre uma área nos estudos de vestuário pouco contemplada, a confecção industrial de roupas.

\section{1 - Padrões de análise}

\section{BARTHES, Roland. Sistema da moda.Tradução por Lineide do Lago Salvador Mosca. São Paulo: Editora Nacional/EDUSP, 1979, 301 p. (FSM, LET/USP, FD/USP, MP/USP)}

No horizonte do trabalho de Barthes, cuja primeira impressão é de 1967, encontra-se o problema da fundamentação de toda a análise semiológica mas ele o desenvolve a partir de um objetivo mais específico, a análise estrutural do vestuário feminino, realizada sobre alguns importantes jornais e revistas franceses de moda publicados entre junho/58 e junho/59. Este é um dos grandes méritos deste livro. Ao invés de simplesmente adotar a idéia bastante difundida de que o vestuário é um sistema de comunicação e, portanto, constitui uma linguagem, o A. preferiu o exame minucioso e sistemático de todos os passos que levam do objeto (roupa) ao signo (signo vestimentário) explorando em detalhe as implicações de concebermos um segmento do universo material, o vestuário, como linguagem. No entanto, podemos constatar que a produção de sentido no universo material só ocorre para o A. quando se assemelha ao funcionamento do signo lingǘstico. Trata-se não de buscar a especificidade dos diferentes sistemas - lingǘísticos e não-tingüísticos - mas de submeter toda significação à análise lingüística. 
A questão que perpassa todo o estudo de Barthes é a expansão de postulados do estruturalismo lingüístico saussuriano para outros campos de conhecimento. Sua abordagem, no entanto, não é desenvolvida a partir da completa identificação entre vestuário e linguagem mas sim na plena vigência de um dos postulados principais da análise estrutural: a produção de sentido ocorre fundamentalmente a partir da combinação de estruturas invariáveis: Vamos nos limitar aqui a acompanhar os procedimentos do A. para definir a estrutura própria do vestuário de moda.

Logo no prefácio, o A. deixa claro que seu trabalho trata especificamente da análise da descrição textual das roupas de moda - a Moda escrita - que encontrou naqueles periódicos e não das imagens que veicularam ou das roupas efetivamente utilizadas pelas pessoas (respectivamente o vestuário-imagem e o vestuário real). Observa, no entanto, que sua opção pela Moda escrita não significaria realizar uma análise lingǘstica do vestuário. Não se pode evitar o exame de enunciados verbais mas a pesquisa busca, na verdade, os traços vestimentários que anteriormente à sua apreensão através de signos lingüísticos formariam já um sistema de significação.

Barthes afirma inicialmente que "não se pode definir uma estrutura fora da identidade substancial das unidades que a compõem" (p.7). Importa definir as estruturas de um sistema de sentido se desejamos compreender seu funcionamento e esta definição implica examinarmos o tipo espećífico de unidades que ele contém. Se formos estudar um fenônemo como a moda em vestuário encontraremos as três estruturas referidas anteriormente: o vestuário escrito, que é composto por palavras em relação sintática (estrutura verbal); o vestuário-imagem com suas formas, linhas, superfícies e cores, numa relação espacial (estrutura icônica); o vestuário real cuja composição depende dos atos de sua fabricação: o corte, a costura etc. (estrutura tecnológica).

Um estudo completo do vestuário de moda deve ater-se em primeiro lugar a cada uma dessas estruturas separadamente. Um estudo rigoroso de uma delas deve considerar que na concepção e difusão de uma roupa de moda todas elas são mobilizadas mas a passagem de uma para a outra - da roupa fabricada para sua foto e para sua descrição na revista - é sempre descontínua, iá que tratamos com diferenças estruturais. Assim, existem determinados dispositivos que permitem estas passagens mas não podem ser considerados tradutores e sim designados embreantes: operadores que permitem a passagem de uma estrutura a outra: o molde de costura para a passagem do vestuário real ao vestuário icônico; a receita ou programa de costura (instruções escritas) do vestuário real ao vestuário escrito; os anafóricos da língua do vestuário icônico ao escrito.

Vê-se que também aqui prevalece o esforço de distinção entre as estruturas mas não para garantir a forma específica com que cada uma pode produzir sentido mas para afirmar que o sentido só é plenamente realizado através de signos lingüisticos. Entre as vantagens metodológicas para a escolha do vestuário escrito, em detrimento do vestuário real e do vestuário icônico, para análise do sistema de significação, está o fato de que o primeiro seria embaraçado por finalidades práticas (proteção, pudor, adorno) e o segundo por uma função estética. Apenas o vestuário escrito é concebido unicamente para a significação. Desta forma, temos que a produção de sentido é ótima quando ocorre na linguagem ou 
se assemelha a seu modo de funcionamento baseado na combinação de estruturas elementares. A procura destas estruturas não pode afastar-se, por princípio, de uma démarche lingüística. Este será o procedimento de Barthes.

A relação entre o signo lingǘstico e o que o $\mathrm{A}$. denomina signo vestimentário é complexa e não de simples redução do segundo ao primeiro. Devemos considerar de início que diferenças estruturais são irredutíveis - as roupas $e$ as palavras que as descrevem são substancialmente distintas - $e$, portanto, a proposta de reconstituir o vestuário de moda como sistema de sentido implica trabalharmos com os elementos e funções exclusivos deste sistema. No entanto, argumenta o A., a análise formal de sistemas está mais desenvolvida na lingüística e é nela que devemos apoiar nossos primeiros passos no encaminhamento dos problemas formulados. De fato, o conceito de estrutura ele buscou em Hielmslev (p. 3, nota 2); retirou a noção de embreante dos trabalhos de Jakobson, ampliando-a (p.6, nota 7); anáfora veio de L. Tesnières (p.7, nota 10); adotou procedimentos expositivos da lingǘstica (p. 11, nota 23); utilizou a palavra termo para indicar que trabalhava com a noção de sistema como havia feito Saussure (p. 19, nota 2) e é também neste autor que foi buscar o conceito de signo (p.25).

Para tomar o vestuário de moda como um sistema formal, portanto, disponivel para a análise estrutural, o A. buscou o modelo fornecido pela lingüística e se a utilização daquela terminologia seria apenas elementar, o primeiro passo efetivo nesta direção seria a definição de classes comutativas no vestuário de moda, através da aplicação da prova de comutação. Chegaríamos, assim, às seguintes classes: Vestuário, Mundo e Moda: todos os termos que compõem os enunciados de moda provêm de uma destas classes (esmagadoramente das duas primeiras permanecendo quase sempre implícito para a última). Afastamo-nos, já neste passo inicial, das classes gramaticais para adentrarmos aquelas que seriam próprias da moda escrita. Será, portanto, um certo funcionamento sistemático que aproximará o sentido na linguagem e o sentido no vestuário.

É dos tipos de relação que estabelecem entre si estas classes (segundo dois conjuntos possíveis: Vestuário f Mundo; Vestuário $f$ [Moda]) que se organiza o significado. Barthes demonstra que quanto à sua natureza quase todo tipo de relação (finalidade, causalidade, Iransitividade, circunstância) pode-se estabelecer entre os termos das classes comutativas mas estruturalmente, ou seja, na sua forma mais geral e invariável, as relações são todas de equivalência. Mas esta é também uma relação orientada: os termos abstratos do Mundo e da Moda são manifestados pelos objetos materiais do Vestuário e assim sendo, os enunciados da Moda funcionam plenamente como signos na acepção saussuriana: reunião de um significante material e de um significado imaterial. Resumidamente, a análise dos enunciados de moda não é a análise lingüística das "palavras" que os compõem mas dos termos significantes e significados provenientes daquelas classes comutativas.

Seguindo este caminho, o pesquisador deverá preocupar-se com dois tipos de análises necessários para compreensão do sistema: uma análise profunda para distinguirmos nos enunciados os seus dois planos significantes; uma análise em extensão - a mais importante pois constitui o fundamento do sistema de signos - centrada na organização dos significantes entre si e que poderá nos dar a relação de um signo com os outros que o cercam. O que o A. procurov estabelecer 
até aqui foi a existência de um sistema vestimentário que, no entanto, só pode ser enunciado através de um sistema lingüístico. Trata-se, portanto, da imbricação de dois sistemas semânticos num só enunciado, problema encaminhado por Hielmslev, conforme nos lembra Barthes na sua busca de recursos lingǘsticos para compreensão do vestuário. Partindo da distinção na língua entre um plano da expressão $(E)$ e um plano do conteúdo $(C)$ que mantêm uma relação $(R)$, formando um sistema, é possivel incluir na análise objetos e imagens, concebendo conjuntos de três sistemas.

Barthes elabora uma representação gráfica para apreendermos melhor sua proposta de análise. Se considerássemos o vestuário de moda em situação teríamos um primeiro sistema significante/significado pois constataríamos o uso efetivo de uma dada roupa numa dada circunstância empírica, funcionando esta roupa como significante do significado constituído pela circunstância. No exemplo de Barthes "os estampados triunfam nas Corridas", os estampados significam as corridas para aqueles que presenciam o evento.

Este primeiro sistema é denominado código vestimentário real. No enunciado impresso numa revista de moda, este sistema inteiro passa a constituir o significado de um sistema terminológico ao qual corresponde um significante, que é a frase. A notação na revista não visa apenas expor a equivalência estampados/corrida mas a exibíta como Moda. Portanto, esta notação do enunciado é por sua vez significante do significado Moda, formando um terceiro sistema. Finalmente, o quarto e último sistema denominado retórico: o enunciado considerado encontra-se numa fraseologia de uma revista específica que não só afirma uma roupa como roupa de moda como elabora uma representação da moda e do mundo (no exemplo, a moda utilizada nas corridas é tomada como competição se observarmos a fraseologia na qual temos o termo "triunfar").

Toda esta reflexão refere-se ao primeiro tipo de equivalência Vestuário 三 Mundo; a equivalência Vestuário 三[Moda] necessitou de novas considerações mas apenas como uma variação dentro da mesma análise. $\bigcirc$ esquema para a primeira equivalência, mais ampla, apresentado por Barthes é o seguinte:

\section{ESQUEMA 1}

4. Sist. retórico

3. Conotação de Moda

2. Código vest. escrito

1. Código vest. real

\begin{tabular}{|c|c|c|c|c|}
\hline \multicolumn{4}{|c|}{$\begin{array}{l}\text { Se: } \\
\text { Fraseologia } \\
\text { do jornal }\end{array}$} & $\begin{array}{l}\text { So: } \\
\text { Representação } \\
\text { do mundo }\end{array}$ \\
\hline \multicolumn{3}{|c|}{$\begin{array}{l}\text { Se: } \\
\text { Notado }\end{array}$} & $\begin{array}{l}\text { So: } \\
\text { Moda }\end{array}$ & \\
\hline \multirow[t]{2}{*}{$\begin{array}{l}\text { Se: } \\
\text { Frase }\end{array}$} & \multicolumn{2}{|c|}{$\begin{array}{c}\text { So: } \\
\text { Proposição }\end{array}$} & & \\
\hline & $\begin{array}{l}\text { Se: } \\
\text { Vest. }\end{array}$ & $\begin{array}{l}\text { So: } \\
\text { Mundo }\end{array}$ & & \\
\hline
\end{tabular}


Definidas as classes comutativas que contêm todos os termos de moda e definidos os sistemas ao longo dos quais se distribuem estes termos, deve-se partir para a busca das unidades estruturais mobilizadas para produção de sentido. Barthes propõe dois tipos de operações para tal fim: de transformação, que promove a redução dos sistemas entre si afim de encontrar os elementos básicos do enunciado que mobilizam os caracteres físicos da roupa de moda na produção de sentido; de recorte, que isola significantes e significados permitindo a análise de cada qual separadamente, sobretudo dos primeiros que constituiriam as unidades produtoras do sentido.

Quanto à transformação, duas são necessárias. A transformação do sistema retórico no código vestimentário escrito é simples nos próprios termos do A., trata-se de passarmos de enunciados tais como "à tarde, os vestidos franzidos se impõem" ou "que toda mulher use escarpins bicolores" para "vestidos franzidos são signo da tarde" ou "os escarpins bicolores significam a moda". $O$ mais importante para nosso propósito aqui é, no entanto, a segunda transformação, do código vestimentário escrito em código vestimentário real, quando a irredutibilidade do objeto roupa à linguagem que a ele se refere e a necessidade de ser veiculado por ela apresentam-se inteiramente: "na realidade, deve-se reconhecer que o sentido vestimentário, que é o próprio fim enunciado, é estreitamente tributário do nível verbal... A língua é um limite além do qual o sentido se irrealiza, e, no entanto, as relações da língua não se podem identificar com as do código vestimentário real" (p.45). A solução proposta é manter os termos do sistema vestimentário escrito ou sistema terminológico (as unidades da língual mas transformar as relações gramaticais em funçōes lógicas mais amplas - equivalência e combinação foram as imediatamente utilizadas - que poderiam, então, expressar as relações do vestuário real.

Barthes chegará ao que denomina enunciados semiverbais, semialgorítmos. Assim o enunciado verbal "Os trajes da cidade pontuam-se de branco" transforma-se no seguinte:

no código vestimentário escrito ou sistema terminológico

no código vestimentário real

Onde

- combinação

三 equivalência pontos brancos sobre um traje são um signo de cidade

traje $\bullet$ pontos $\bullet$ branco $\equiv$ cidade

Neste ponto atingiríamos o máximo de aproximação do vestuário real: quando ele se constitui como um código que contém termos linguísticos regidos por uma lógica ampliada em relação à gramática da língua (Barthes denomina-o, a partir desta constatação, de código pseudo-real). Embora possamos chegar a esta imbricação entre linguagem e roupa de moda para compreender a produção do sentido no sistema de vestuário, podemos perceber que efetivamente o que diz respeito a objetos ou situações extra-lingǘsticos são as relações suficientemente 
formais para integrarem elementos de outros sistemas não-lingüísticos. Se perguntarmos o que é roupa nesta análise estrutural, perceberemos que apenas aqueles elementos do vestuário que têm uma referência lingüistica podem ser considerados como tal - aquilo que não for nomeado não existe como roupa de moda, pois a Moda só existe, só constitui sentido na língua e, fora daí, se acaso quiséssemos decompor um traje descrito em seus elementos técnicos ou veiculados em imagem, teríamos apenas "uma predileção para certas formas ou certos detalhes" e a moda não ascenderia nunca ao status de "elaboração ideológica".

É preciso reconhecer a preocupação e o esforço do A. em distinguir língua e vestuário, sobretudo quando discorre sobre a relação entre os dois códigos. Como afirmamos acima, não é através da identificação de estruturas vestimentárias e lingüísticas que a análise lingüística recobre em Barthes a semiologia do vestuário de moda mas sim na possibilidade de encontrarmos estruturas invariáveis a partir das quais se produz toda significação possiviel. Assim, a pesquisa pela definição da estrutura própria a cada código refórça ao mesmo tempo o postulado de que todo sistema de comunicação funciona no modo definido para o sistema lingǘstico: a combinação de estruturas elementares.

A unidade estrutural seria o ponto chave de toda a análise de um sistema de comunicação. Definindo-a é possivel reconstruir o sistema inteiramente e Barthes estabelece efetivamente esta unidade. Aplicando a prova de comutação à seguinte frase que contém dois enunciados, "cardigã esporte ou social conforme a sua gola seja aberta ou fechada" pode distinguir o elemento cuja variação produz também uma variação de sentido, fornecendo-nos a seguinte notação:

$$
\begin{aligned}
& \text { cardigã } \bullet \text { gola } \bullet \text { aberta } \equiv \text { esporte } \\
& \text { cardigã } \bullet \text { gola } \bullet \text { fechada } \text { Esocial }
\end{aligned}
$$

Observa-se que é o fechamento ou a abertura de uma parte da peça de roupa que modifica o sentido (esporte ou sociall) mas ao mesmo tempo é a peça como um todo que recebe o sentido. Assim há uma solidariedade de elementos que produz o sentido. Nenhum sozinho seria capaz de fazê-lo e, portanto, a unidade é a composição destes elementos solidários. Seriam, enfim, o Objeto $|O|$ visado pela significação (o cardigã), o Suporte (S) que recebe a variação e a transmite ao objeto (a gola) e o elemento Variante (V). Esta seria a unidade estrutural procurada na sua definição mais formal - é ela que pode receber os mais diferentes conteúdos (os traços vestimentários; as possibilidades de variação) e, portanto, constitui propriamente uma matriz significante a partir da qual se erige o sistema por inteiro.

Barthes define um símbolo gráfico a partir de um enunciado simples para torná-la mais apreensivel:

$$
\frac{\text { uma malha de gola fechada }}{O} \mathrm{~S}_{\mathrm{V}} \mathrm{social}
$$

Vimos que o que se espera desta matriz não é pouco: é ela que decifra o funcionamento de todo o sistema de comunicação. Ela terá aproximações com as unidades lingüísticas; Barthes mesmo diz que, em termos da lingüistica, seu 
trabalho é definir no sistema suas unidades sintagmáticas e suas oposições sistemáticas (p.57) mas este terá também suas especificidades, como a existência do suporte, que não produz ou recebe o sentido mas só o transmite, diferentemente do fonema, que sendo variante é também significante (p.63); ou a exclusividade da variante como a parte da unidade sintagmática na qual operam as oposições sistemáticas enquanto na língua todos os pontos dos sintagmas, fonemas ou monemas, surgem destas oposições (p.65); ou ainda a intercambialidade de substâncias (conteúdos) entre os elementos no interior da matriz (uma blusa ou um traço vestimentário qualquer podem ser objeto ou suporte) ao passo que na língua a cada forma (fonema) corresponde uma substância fônica (p.67).

Estas diferenciações decorrem da originalidade do elemento suporte, no interior da matriz, ao mesmo tempo material e inerte. Uma matéria inerte na matriz do sistema de significação permite a Barthes supor que ela seja um elemento específico dos sistemas de comunicação que se apoiam em objetos materiais, isto é, não concebidos unicamente para significar como a língua mas para uma finalidade técnica ou funcional.

As diferenças entre sistemas lingüisticos e não-lingüísticos param por aqui em Barthes. Ambos só funcionam como sistemas a partir do estabelecimento e combinação das unidades estruturais próprias. Ao pesquisador do vestuário de moda que procurar compreendê-lo como linguagem Barthes mostra os procedimentos que obrigatoriamente ele deve desenvolver: percorrer o longo caminho que se inicia pela busca das unidades elementares de sentido e a reconstrução do sistema a partir delas.

\section{SAHLINS, Marshall. Notas sobre o sistema do vestuário americano. \\ In: Cultura e razão prática. Tradução por Sérgio Tadeu de Niemayer Lamarão. Rio de Janeiro: Zahar, 1979 p. p9-225. (FIL/USP, MP/USP)}

O trabalho de Marshall Sahlins é importante para nós porque, em primeiro lugar, da mesma maneira como Barthes, preocupou-se em fundamentar um método para estudo sistemático do vestuário como sistema de comunicação, procurando evidenciar as dificuldades e todo o caminho que se apresentam aos pesquisadores que desejarem realizar análises consistentes neste campo. Em segundo lugar, porque ao contrário de Barthes, que se restringiu ao exame dos enunciados verbais sobre a roupa de moda, $\circ$ A. desde o início voltou sua atenção para todos os tipos de vestuário, tomados em sua materialidade. É a produção de sentido a partir das roupas enquanto objetos físicos o problema colocado por ele.

A solução apresentada pelo A. para encaminhamento dos problemas nesta área é desenvolver uma análise estrutural do vestuário. No entanto, neste texto não realiza sua tarefa a partir da exposição exaustiva de um método mas apenas esboçando os contornos gerais de sua abordagem. É um texto estratégico para compreensão do seu posicionamento ante a questão em função de algumas limitações que ele mesmo se impôs e que nos conduzem aos principais conceitos e noções empregados no trabalho. Uma primeira limitação decorre do fato de que o seu interesse principal está em analisar as relações entre produção econômica e cultura nas sociedades capitalistas, constituindo o sistema do vestuário um dos 
exemplos através dos quais se pode indicar que organizando a produção de mercadorias no sistema capitalista está um código simbólico dos objetos, muito além do simples jogo dos interesses econômicos na relação oferta/demanda lo outro exemplo refere-se às razões culturais dos hábitos alimentares analisadas na criação de animais domésticos). De fato, boa parte de suas considerações sobre - vestuário norte-americano é uma discussão mais genérica sobre as maneiras pelas quais as características físicas dos objetos (formas, cores etc.) podem constituir-se em produtos/vetores de significações sociais.

Sahlins não tem por objetivo analisar as roupas em "contexto de situação", isto é, estudar como efetivamente as pessoas se vestem pois este seria o problema específico do "sistema em ação", cujo encaminhamento mais seguro requereria a análise prévia do sistema em si mesmo. Seria necessário antes apreendermos todo o potencial do sistema para produzir sentido e examinarmos em seguida as apropriações efetivas do vestuário que as pessoas realizam para significar as relações sociais.

Considerando, então, o sistema do vestuário, encontraríamos nele uma variada gama de categorias culturais. As roupas podem demarcar a diferenciação do espaço cultural entre campo e cidade, centro e bairros residenciais, espaço público e espaço domésticofamiliar e mais além, as diferenciações entre regiões no interior de um país; podem significar as noções de tempo: noite, tarde, dia, diário, semanal, sazonal; e ainda diferenças de status segundo classe social, gênero, etnia e grupo etário. A análise do vestuário deve permitir-nos avaliar como neste segmento do mundo físico estabelecem-se as diferenciações significativas entre todas essas categorias culturais. O A. se restringirá ao exame das categorias que podemos definir para as atividades sociais do lazer e trabalho no propósito de indicar a eficácia de duas regras sistemáticas que organizariam a produção de sentido no vestuário norte-americano contemporâneo e com elas sugerir a existência de todo um conjunto de regras aplicáveis a este universo de categorias culturais.

Abandonando a pretensão de realizar um estudo mais completo do vestuário, o A. centra-se nos aspectos que julga essenciais para analisáto como sistema de comunicação, apresentando, assim, os fundamentos de sua análise estrutural. Dois pontos apresentam-se aqui para discussão: 1) a concepção do método para análise de sistemas de comunicação não-lingǘsticos a partir da aplicação de conceitos e noções desenvolvidos em lingüística; 2) a concepção idealista de cultura: o sentido preexiste à organização social, localizado em "estruturas mentais".

Podemos afirmar, resumidamente, que as noções de sistema e esquema utilizadas pelo $\mathrm{A}$. para análise do vestuário norte-americano lhe sugerem a existência de um conjunto de regras a partir das quais partes componentes do sistema estabelecem relações entre si. O problema decorrente de sua formulação é a necessidade de definir as unidades básicas do sistema e o modo de elaboração e funcionamento das regras. Do início ao fim desta proposta encontramos uma abordagem lingüística para estudo das características físicas das roupas.

Pode-se constatar facilmente como toda a sua terminologia provém do campo lingüistico. Estabelece como objetivo da análise encontrar a sintaxe geral - o conjunto de regras de declinação e combinação das classes de forma-vestuário 
- que permitiria através das roupas a formulação de uma gama considerável de proposições sobre "as relações entre pessoas e situações no sistema cultural". Tratar-se-ia de estabelecer a gramática do vestuário. Quanto aos autores utilizados no texto, para avaliarmos a importância daqueles que pensaram a semiologia a partir da lingüística, não temos apenas uma citação aqui e ali de Saussure sobre combinação de unidades sintagmáticas ou sobre a distinção entre langue e parole mas, sobretudo, a especificação de diferenças com relação à abordagem de Barthes e a concomitante utilização de certos resultados de pesquisa obtidos em "Sistema da moda".

Acrescente-se que o A. é muito conseqüente com o uso que faz daquelas noções. Se há uma gramática que organiza o vestuário então ele funciona como um sistema, o que significa afirmar, num nivel descritivo, que possui elementos organizados em unidades e classes cujas relações obedecem a regras específicas. Uma característica dos sistemas é sua abertura que thes permite responder à ocorrência de mudanças, tornando-se mais amplos e complexos mas sem alteraremse a si mesmos. Os sistemas tendem à conservação, a manter sua identidade incorporando mudanças. É este esquema do funcionamento sistemático que Sahlins utiliza para compreender diferenciações que se podem verificar no vestuário norteamericano. Ele observa que a divisão entre bebês e crianças em idade escolar torna-se mais complexa quando se analisa os tipos de roupas veiculadas na publicidade, até atingir pelo menos quatro categorias; o mesmo vale para adolescentes e para os gêneros (nestes até mais de seis categorias). Mas não devemos considerar apenas a multiplicação de categorias mas também as adaptações de distinções de uma parte do sistema para outra, como seria o caso da apropriação do blue jeans pela juventude norte-americana le também em outras regiões do mundol utilizando, no sistema do vestuário, o contraste das categorias adolescente/adulto: trabalhador/capitalista para contestação política (pode assim avaliar que a mudança no vestuário "jovem" não constituiria uma ruptura na sociedade capitalista, posto que esta funciona como sistema).

Todos esses aspectos do seu trabalho são indícios da abordagem que desenvolve mas podemos perceber, de fato, como a lingüistica estrutural a organiza, observando que ele tomou exatamente o caminho de Barthes para compreender o vestuário como um sistema: a definição das regras de seleção e combinação de unidades elementares.

Quanto às regras, trabalhando com um esquema de funções baseado na distinção proposta por Véblen entre duas grandes categorias de atividades cerimônia e trabalho - pode sugerir a existência de pelo menos duas regras sistemáticas da sintaxe pressuposta para produção de sentido no vestuário. Fornecemos uma representação gráfica baseada no esquema elaborado pelo $\mathrm{A}$. para facilitar a compreensão da argumentação desenvolvida (esquema 2 ).

Discorrendo sobre o tipo de vestuário utilizado pelas pessoas em cada atividade de trabalho ou situação cerimonial, desenvolve as considerações seguintes. Se compararmos, por exemplo, um smoking, traje masculino pertencente à classe Ocasiões Especiais (Fête) com os trajes da classe imediatamente mais próxima dos Esportes e compararmos também outro par, como um terno pertencente à classe Executivo com um traje da classe Funcionário de Escritório, veremos que as diferenças que separam os trajes marcados (formais), sempre à esquerda no 


\section{ESQUEMA 2}

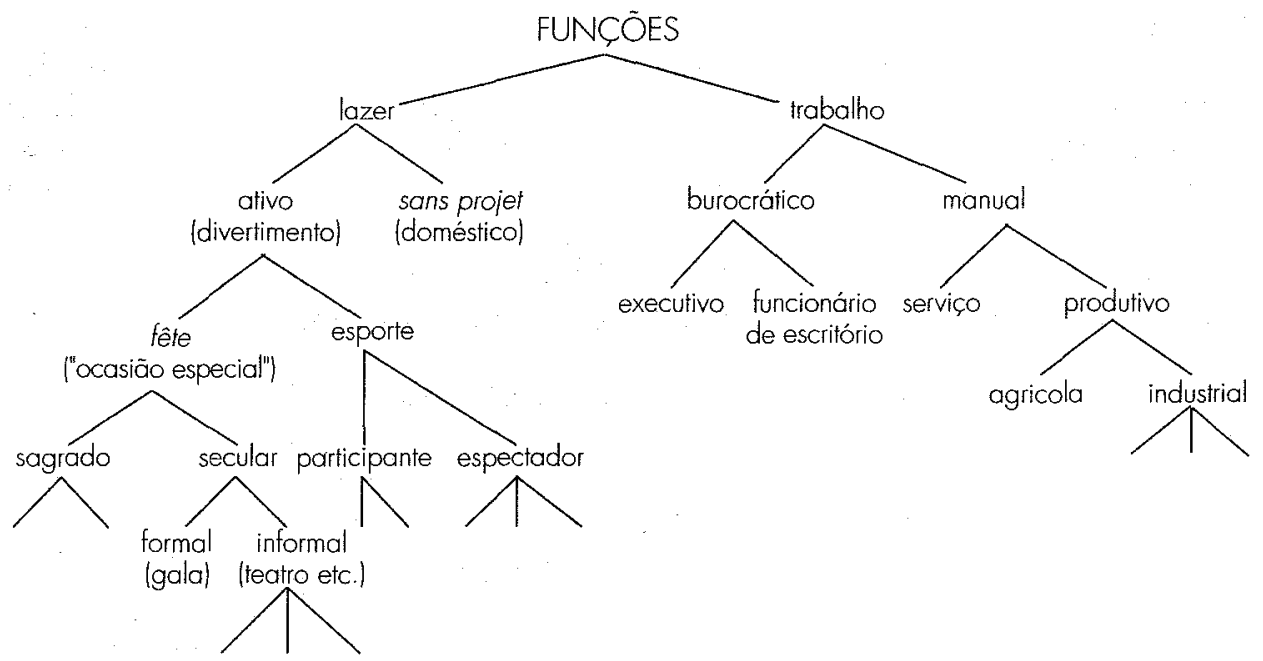

gráfico, dos trajes não-marcados (informais) é a mesma. O mesmo sucederá se considerarmos quaisquer pares do esquema, ocorrendo uma diferença entre formalidade e informalidade que tende a reproduzir a distinção maior entre cerimônia e trabalho. Assim, retomando o exemplo, o terno do executivo de certa forma assemelha-se mais ao smoking e afasta-se do traje de funcionários de escritório. Segundo o A. observamos uma similitude de diferenças que indica a existência de uma regra do sistema que ele denomina regra de correspondência cerimonial, assim definida: "os termos de qualquer oposição correspondem aos termos de qualquer outra, de tal forma que as roupas marcadas (cerimoniais) de quaisquer de duas classes se parecem entre si por uma diferenciação análoga em relação às roupas não-marcadas (próprias do trabaho) de suas respectivas classes".

Outra regra pode ser esboçada a partir da mesma distinção cerimônia/ trabalho. Se tomarmos os exemplos anteriores poderemos observar que o smoking é mais cerimonial do que o terno do executivo embora este seja mais marcado (formal) em relação ao traje dos funcionários de escritório; também se observa que os trajes-esporte embora não-marcados (informais) em relação ao smoking são menos próprios ao trabalho que o traje de funcionário de escritório (informal); ainda assim se compararmos os trajes das classes Trabalho Burocrático e Trabalho Manual veremos que os trajes dos funcionários de escritório embora não-marcados são menos próprios ao trabalho (tendem ao cerimoniall), comparativamente aos trajes da classe Trabalho Industrial e o terno é mais cerimonial do que os trajes da classe Serviço. Temos aí a regra do exagero cerimonial: "a oposição estipulada dentro de uma classe própria do trabalho é exagerada pela oposição correspondente numa classe mais cerimonial".

O importante para nós, em toda esta argumentação desenvolvida pelo A., é que dois requisitos prévios foram necessários para este exercício de definição de regras sistemáticas para a produção de sentido no vestuário. Todo o esquema 
organiza-se em classes e sub-classes compostas todas por dois tipos de elementos em oposição: marcados (formais) sempre à esquerda e não-marcados (informais). O esquema baseia-se na distinção entre duas "modalidades do discurso social", faire e être, discutidas por Barthes, à qual o A., por um lado, faz corresponder para seus propósitos a distinção entre função e status ocupacional e, por outro, aplica à primeira modalidade uma outra distinção, aquela proposta por Veblen, entre as categorias de cerimônia e trabalho. $\mathrm{O}$ A. deixa claro que não as discute, apenas toma-as como pressupostos para seu trabalho mas percebemos que só podem funcionar como tais na medida em que todas as distinções estabelecidas tornem-se classes paradigmáticas, uma das condições prévias para que a produção de sentido possa ocorrer. É somente quando os tipos de classes de elementos dos sistemas lingüisticos têm possibilidade de ocorrer no vestuário é que este pode tornar-se um sistema de comunicação.

O outro requisito é que certas regularidades observáveis no esquema sejam consideradas regras. Esta passagem é necessária, do ponto de vista assumido pelo A., para que o vestuário produza sentido da mesma maneira que os sistemas lingüísticos, ou seja, toda ocorrência no sistema só se dá no funcionamento do próprio sistema, que tenderia então a reproduzir-se e a incorporar toda mudança localizada que surja no seu interior. É este funcionamento sistemático que deve ser encontrado no vestuário, não cabendo aí estabelecer simples regularidades, que sendo apenas isso, poderiam ocorrer transitoriamente, surgirem de fora do sistema e modificarem-se à menor mudança introduzida.

É por isso que funcionando sistematicamente e não de forma aleatória, sujeita a mudanças "exteriores", exatamente como o previsto para os sistemas lingüísticos, a produção de sentido no vestuário é passivel de formalização lógica. Assim, a regra de correspondência cerimonial pode ser expressa da seguinte forma: $M x / \bar{M} x \sim M y / \bar{M} y$ - a oposição do marcado $(M)$ e não-marcado $(\bar{M})$ em qualquer classe $(x)$ corresponde ( ) a $M / \bar{M}$ em qualquer outra classe (y). A expressão para a regra do exagero cerimonial é a seguinte: $M x^{1}>M y^{2}:: M x^{1}<M y^{2}$, onde os expoentes $(1,2,3 \ldots \mathrm{n})$ representam um fator da função do trabalho e $>$ e $<$ representam formalidade relativa (há também um diagrama para esta regra, p.209).

Mas para que o vestuário seja um sistema comunicativo ele deve conter unidades mínimas a partir das quais o sentido pode organizar-se. Uma vez determinada, segundo o caminho proposto, a possibilidade de encontrarmos regras de produção de sentido no vestuário, seria preciso definir a quais características físicas das roupas as regras se aplicariam - as cores e seus contrastes, o tipo de corte, o modelo, as peças do vestuário e suas combinações, as diferentes texturas e dimensões, etc. Trata-se de definir quais são os elementos do sistema sujeitos às regras. Neste ponto o A. sugere que o melhor é definirmos o nível mais baixo das unidades significativas do sistema cuja denominação ele propõe sejam UCEs (unidades componentes elementares). Esta operação seria necessária porque haveria no vestuário vários níveis de produção semântica - conjunto de peças, peças e partes de peça - e deveríamos partir não das unidades mais complexas pois que o significado nelas é estabelecido no nivel das unidades mais simples. A função destas unidades é clara. $\bigcirc$ A. evita chamá-las "vestemas" preferindo a solução acima, um tipo de observação que Barthes fez a propósito dos "gustemas" sugeridos por Lévi-Strauss. Trata-se em todos esses casos de aproximar de alguma forma o 
tipo de unidade elementar estabelecida das unidades elementares da lingüística, os fonemas. Estes, em classes paradigmáticas e veremos que as classes propostas para as unidades de vestuário serão classes deste tipo.

Estaríamos, assim, buscando os contrastes binários nos quais organizam-se os significantes, exatamente como Saussure sugeriu para os sistemas lingǘsticos. A. propõe três classes de unidades elementares, a saber, textura, linha (no Brasil, o corte: reto, arredondado, etc.) e cor. Continuando seu estudo prospectivo, comenta rapidamente, para as duas primeiras classes, estudos de especialistas em vestuário ou psicologia experimental para indicar como contrastes objetivos nas roupas são utilizados - ou estão potencialmente disponíveis - para produzir diferenças de significado. Assim é que listas de qualidades opostas de textura - as fazendas podem ser opacas ou brilhantes, ásperas ou lisas, rijas ou flexíveis etc., considerando-se ainda gradações e combinações - apresentam uma relação de pólos opostos a partir dos quais podemos esperar que a uma característica objetiva possa ser atribuído um significado específico. O mesmo ocorre com as características da linha - direção (vertical, horizontal, oblíqua), forma (reta, curva, angular, zigue-zague), ritmo (ondulante, oscilante, etc.) - a cada qual podendo-se atribuir significado, conforme indicam estudos em arte e psicologia experimental. A última classe considerada - a cor - coloca um outro tipo de problema assim formulado pelo A.: "Ora, como se chega da característica de objeto da UCE (por exemplo, reto/curvo) à sua significação cultural (masculino/feminino)?". O encaminhamento deste problema envolve a consideração de um outro posicionamento básico e que orienta toda sua abordagem: a concepção específica de cultura que sustenta seu texto. Em suma, ela tende a ser uma concepção idealista. Abrindo um parênteses nas suas colocações iniciais sobre o vestuário, retorna brevemente aos problemas principais tratados no livro e afirma que a "visão da produção como a substancialização de uma lógica cultural" invalidaria, como simplesmente idéias do senso comum ou como ideologias, proposições como "a demanda gera a oferta" (mistificação ideológica dos produtores) ou, ao contrário, "a oferta gera a demanda" (denúncia pouco crítica que supõe o domínio de alguns poucos "tomadores de decisão"). A produção é resultado de um proceșso: uma determinada lógica cultural converte-se em objetos físicos. $O$ que tentamos tornar claro aqui é que, para o A., a relação entre produção material e organização do sentido tem uma direção específica. Ele considera primeiramente que haveria aí uma dialética: "O produto que chega a seu mercado de destino constitui uma objetificação de uma categoria social, e assim ajuda a constituir esta última na sociedade; em contrapartida, a diferenciação da categoria aprofunda os recortes sociais do sistema de bens". Esta dialética, no entanto, apenas afirma que a categoria social realiza-se efetivamente quando se converte em objeto e que à diferenciação de categorias correspondem as divisões no sistema de bens. Afirma-se, portanto, que a produção material se realiza a partir da organização de sentido numa formulação que torna sem validade o movimento contrário, isto é, que a organização do sentido se realiza a partir da produção material. Entende-se melhor a sua conclusão a respeito: o capitalismo não é apenas a racionalidade do mercado, é também "uma forma definida de ordem cultural, ou uma ordem cultural agindo de forma particular".

Trata-se de concebermos, então, que a produção material serve à 
organização do sentido na sociedade e não corresponde tão somente à satisfação de interesses e necessidades de produtores e consumidores. Desta forma, compreender a cultura exige compreender as relações entre ela e o mundo físico. É neste problema que desemboca a reflexão desenvolvida sobre o vestuário como sistema de significação. $\bigcirc \mathrm{A}$. procura demonstrar, então, que não podemos derivar os conteúdos atribuídos às distinções na cultura (feminino/masculino, autoridade/ subordinação, etc.) a partir dos contrastes físicos entre as coisas pois estes já são apreendidos segundo significações culturais. Assim é o caso para a definição de que linhas retas identificam homens e linhas curvas mulheres: em primeiro lugar, nas distinções culturais termos geométricos são qualidades das categorias estabelecidas loutros exemplos: temos parentes "distantes" e "próximos", o status é uma "posição" entre os homens, etc.) e, em segundo lugar, no mundo físico os contrastes entre objetos são compreendidos não a partir de diferenças objetivas mas segundo qualidades atribuídas la linha curva por ser considerada, já de saida, "feminina" serve para representar a mulher).

Os contrastes físicos entre os objetos não são observados segundo suas diferenças objetivas (são contrastes significativos). Examinando, portanto, a organização do nosso mundo físico, encontramos novamente a cultura que dele se apropriou. A percepção de características físicas dos objetos é um processo semiótico e não apenas um fenônemo físico. Esta forma de argumentação impede que possamos buscar na organização do mundo físico - na produção de bens no mercado capitalista, por exemplo - alguma explicação para a organização do sentido. Como entender, então, a elaboração de significados culturais? Se a percepção não é unicamente um fenônemo físico mas processa-se conforme a elaboração da cultura na qual ocorre, isto significa que entre a atribuição de significados e a percepção de características físicas existe um elemento comum organizando-as - o A. argumenta que este elemento é um "estrutura mental". Seria na relação entre estrutura mental e cultura, esta definida como "projeto social de produção simbólica", que poderíamos encaminhar a questão da apropriação cultural do mundo físico de maneira não determinista - a relação enquanto estrutura não possui conteúdos específicos constituindo-se numa relação combinatória formal (uma combinatoire); como uma reserva de potencialidades para a cultura, permite a esta experimentar diversas variações.

O A. desenvolve sua discussão a propósito da cor, mais especificamente sobre uma possível estrutura comum entre os significados das cores e a percepção de suas diferenças. Estudos sobre os significados das cores em diferentes domínios - dispositivos de sinalização como semáforos e bandeiras de quarentena, concepções sobre sexualidade, idades, paixões, etc. - permitem ao A. propor um diagrama dos tipos de relações que as cores podem estabelecer entre si. Desta forma, os pares vermelho-verde e amarelo-azul estariam em oposição semântica e os pares vermelho-azul, vermelho-amarelo, verde-azul e verde-amarelo numa relação de intermediação semântica.

ponto principal é que as pesquisas sobre a percepção visual, tanto em fisiologia - principalmente o processo de transmissão (do olho ao cérebro) da sensação de cor, não se considerando o fenônemo da foto-recepção retinal como em estética, apontam que neste campo encontramos relações equivalentes entre as mesmas cores: vermelho-verde e amarelo-azul constituem duas díades de 
cores opostas enquanto vermelho-amarelo, vermelho-azul, verde-azul e verde-amarelo formam quatro díades de cores compatíveis. Desta forma o A. pode propor que "tal correspondência entre estruturas simbólicas e perceptivas representa uma mobilização das estruturas perceptivas no projeto das estruturas simbólicas" e supor que "esse projeto consiste na reprodução da sociedade num sistema de objetos não simplesmente úteis, mas significativos, cuja utilidade realmente consiste em uma significação".

LIPOVETSKY,Gilles. Império do efêmero: a moda e seu destino nas sociedades modernas. Tradução por Maria Lúcia Machado. São Paulo: Companhia das Letras, 1989, 294p. (ECA/USP, FE/USP, FIL/USP, FSM, MP/USP)

A. é professor de sociologia e seu trabalho, entre os livros traduzidos no Brasil nos últimos anos, é seguramente aquele no qual encontramos formulados e encaminhados com maior precisão e abrangência os principais problemas referentes aos estudos sobre moda. De maneira mais específica sua pesquisa desenvolve-se como uma história da modá, estabelecendo recortes precisos la partir de critérios claramente expostos) afim de que possamos, em meio à enorme massa de informações, apreender as linhas gerais de seu desenvolvimento e as razões para as mudanças verificadas. Afasta-se, assim, da crônica linear e cronológica de eventos que caracteriza muitas obras neste campo e procura uma salutar renovação das análises tradicionalmente oferecidas; ao mesmo tempo, porém, desenvolve uma concepção de história que dissocia práticas e representações e traz muitas desvantagens para a compreensão do fenônemo. Por isso mesmo é de nosso interesse, após entendermos seus principais argumentos, nos determos nos impasses criados por sua abordagem.

Uma das principais questões formuladas pelo A. refere-se à centralidade da moda nas sociedades contemporâneas, o que a constitui como força efetiva na produção e reprodução social. A moda que surgiu como um fenômemo muito localizado na modernidade - nas cortes européias e por muito tempo restrito aos estratos sociais dominantes - experimentou um paulatino desenvolvimento até tornarse um fenônemo onipresente e força hegemônica na atualidade; e se, até poucas décadas, ainda estava restrita a determinados estratos da população, hoje insinua-se fortemente em faixas etárias e classes sociais que antes não alcançava. Sua intensa difusão constituiria um processo fundamental das sociedades pós-industriais, fato que motiva uma dura crítica do $A$. à intelectualidade, em razão da marginalidade do tema nos estudos acadêmicos.

Esta reduzida exploração do assunto teria conduzido a um enfoque empobrecedor para compreensão das variações sucessivas que caracterizam a moda ao vinculátlas exclusivamente às estratégias de distinção social quando, na verdade, teriam surgido associadas a dois valores fundamentais da modernidade: a importância do novo e a expressão da individualidade. Reclama-se, portanto, a elaboração de uma nova abordagem para compreensão da história da moda e interessa-nos particularmente uma idéia a ela relacionada: "A moda não é mais um enfeite estético, um acessório decorativo da vida coletiva; é sua pedra angular. A moda terminou estruturalmente seu curso histórico, chegou ao topo do seu poder, 
conseguiu remodelar a sociedade inteira à sua imagem: era periférica, agora é hegemônica" (p. 12).

Esta força estruturante da moda na organização social corresponde à realização de sua própria história, o que supõe a seguinte concepção: elementos que estavam potencialmente contidos nela desde seu surgimento realizaram-se plenamente na atualidade; o valor do novo e a expressão da individualidade, elementos que caracterizariam a moda hoje em dia, estavam implicados na prática da moda desde seu aparecimento no Ocidente. O problema das teorias hoje predominantes sobre o tema, que concebem as estratégias de distinção como o "motor da moda", deve então ser colocado nos termos de uma assimilação da origem da moda a uma de suas funções sociais. A origem de um fenônemo recolheria no seu interior as forças que: se manifestaram num tempo e num espaço geográfico determinados; impulsionaram seu aparecimento; definem sua natureza ainda que não tenham historicamente se efetivado. A função social consiste naqueles usos historicamente realizados (da moda) mas que não constituem necessariamente aquelas forças. O fato de a moda servir à distinção social não define sua verdadeira natureza; esta só pode ser apreendida quando relacionamos sua origem histórica à formação dos valores próprios das sociedades modernas.

Esta mudança de enfoque impor-se-ia também em função das dimensões políticas que ela implica. A consciência renovada que podemos desenvolver da vinculação estrutural da moda àqueles dois valores da modernidade seria importante para compreendermos o significado que, de forma paradoxal, o caráter fugidio da moda assumiria na consolidação dos regimes democráticos: quanto mais avança o efêmero mais impulso para a subjetividade autônoma, quanto mais impõe-se a frivolidade mais desenvolve-se uma consciência crítica e tolerante. Na verdade, o autor formula a tese do potencial democrático da moda: ela pode, ao efetivar-se historicamente, à medida que se desembaraça de outras tendências que contem ou dela se apropriaram, realizar os princípios políticos das sociedades liberais e a plena expressão da individualidade humana (não por determinação de uma necessidade histórica mas pela ação consciente dos sujeitos envolvidos).

A. tern a clara intenção de renovar os estudos sobre moda, mas como podemos constatar sentiu-se obrigado a reviver a concepção histórica da "astúcia da razão" (p. 17): a realização histórica da razão através de caminhos, dispositivos, estratégias que aparentemente a contradizem. Este revigoramento de uma concepção histórica de fundo idealista (hegeliano) simplesmente não se aproveita dos recentes desenvolvimentos da pesquisa histórica e prejudica a boa idéia de um questionamento da vinculação exclusiva do estudo da moda às questões de estratificação social. O principal problema que introduz à sua abordagem, como veremos, é uma dicotomia entre história social e história cultural, no entanto, devemos antes disso registrar alguns passos adiante que ela possibilita.

Afirma-se desde a introdução do livro a historicidade da moda, fenônemo específico das sociedades modernas, associado aos valores e formas de socialização próprios deste tipo de organização social. Ao procurar, portanto, elaborar uma abordagem histórica do fenônemo, retira o tema do âmbito das teorias que trabalham com a noção de "natureza humana": a moda não é um fenônemo universal verificável, com maior ou menor intensidade, em toda e qualquer sociedade. Neste aspecto em particular, talvez resida a maior contribuição deste 
estudo. O A. mostra-nos, inicialmente, como não podemos falar em moda nas sociedades tribais, antigas e medievais. De uma maneira variada predomina nestas o valor atribuido à permanência, fato capital que impede a formação do gosto pela mudança, do prestígio do tempo presente e da legitimidade da ação humana sobre o mundo. Assim, de maneira apenas indicativa, o autor nos lembra que a indumentária e seus acessórios, os penteados, as pinturas nas sociedades tribais experimentam mudanças, mas são variações que não escapam às regras fixadas pela tradição; que a toga-túnica egípcia, o peplo grego (traje feminino), a toga e a túnica romanas, o quimono japonês são alguns exemplos de vestuários que permanecem séculos sem conhecerem alterações significativas. Quando ocorrem mudanças na indumentária nestas sociedades, elas decorrem de influências externas - oriundas do contato com outras sociedades, sobretudo nos processos de conquista - ou se verificam em situações muito específicas e localizadas, como a imitação do corte de cabelo e barba de Alexandre pelos gregos ou a variação nos tipos de penteado feminino no Império Romano. Influências episódicas que impulsionam mudanças que tendem a estabilizar-se.

Esta concepção da moda permite sua caracterização mais precisa. Este fenônemo não consiste apenas nas variações ocasionais que podemos verificar, aqui e ali, nas diversas sociedades; a moda como tal exige a constância das variações que têm uma lógica própria ao seu desenvolvimento e que não se deve a influxos exteriores a ela como a imposição de modelos estrangeiros. Acrescentese também uma precaução metodológica pouco observada na maioria das obras sobre moda: a distinção entre moda e vestuário. Dois usos diferenciados do termo são autorizados no senso comum: um ressalta o caráter efêmero das variações e sua ocorrência nas mais diversas atividades - criação musical, reflexão intelectual, no vestir-se, práticas esportivas, elc. - ou tipos de objetos - vestuário e indumentária, interiores de residência, etc.; outro remete exclusivamente ao vestuário, identificação que permite falar, sem maiores preocupações, em moda na Grécia, no Império Romano, nas sociedades da Antigüidade Oriental e outras.

Esta identificação entre moda e roupa, enquanto uso social, deve suscitar muito mais nossa análise do que nossa rejeição mas, no âmbito da pesquisa, torna-se imprecisão conceitual que impede uma correła formulação dos problemas. Quanto aos estudos sobres vestuário, pouca atenção se dá às roupas que se tornam "fora de moda" mas continuam tendo outros usos e às roupas que praticamente desconhecem o fenônemo: as roupas profissionais, eclesiásticas, os uniformes militares. Sobre estas quase não há interesse dos estudiosos e poucas obras pode-se encontrar a respeito, lacuna séria que prejudica uma compreensão mais abrangente e aprofundada das funções do vestuário. Por outro lado, o $\mathrm{A}$. chama a atenção para o fato que as roupas são o "domínio arquetípico" da moda e constituem um meio estratégico para a compreensão deste sistema baseado em variações contínuas; esta observação ao mesmo tempo ressalta uma necessidade para a pesquisa, posto que seria de interesse a análise da moda em outros sistemas de objetos que não o vestuário e em outras atividades sociais nas quais se verifica o fenônemo.

No entanto, estes avanços tópicos que sua argumentação promove são obtidos a partir de uma determinada concepção histórica que compromete seriamente a compreensão das funções da moda na organização das sociedades 
modernas. Podemos acompanhar este problema nas análises do A. sobre a moda durante a Época Clássica e sobre o que denomina moda dos cem anos, um modelo de industrialização da moda marcado pela existência de dois pólos, a confecção industrial e a alta costura e que perdurou de meados do século XIX a meados do século XX. Diante dos reducionismos teóricos que ele julga serem a tônica neste campo, qual o tipo de abordagem que se impõe ao pesquisador?

"Ao contrário do imperialismo dos esquemas da luta simbólica das classes, mostramos que, na história moderna da moda, foram os valores e as significaçóes culturais dignificando em particular o Novo e a expressão da individualidade humana, que tornaram possíveis o nascimento e o estabelecimento do sistema da moda na ldade Média tardia; foram eles que contribuíram para desenhar, de maneira insuspeitada, as grandes etapas de seu caminho histórico" (p. 11 ).

Mais adiante reafirma-se:

"É porque o papel da representação do indivíduo não foi analisado em seu justo valor que as explicações da mudança de moda permanecem tão pouco convicentes... Para que aparecesse o impulso das frivolidades, foi preciso uma revolução na representação das pessoas e no sentimento de si, modificando brutalmente as mentalidades e valores tradicionais" (p.59).

Justa crítica à referência exclusivista do conflito de classes mas que somente articula um outro reducionismo na análise. Problematizada nos termos propostos, a moda não deixa de estar referida à estratificação social mas teria um significado mais profundo na medida em que não funcionaria apenas como mecanismo de diferenciação e hierarquização de classes e grupos sociais; ela seria expressão dos valores que conformariam a cultura moderna. Estes valores são, especificamente, as noções de novo e individualidade. Portanto, é por referência à história cultural - identificada à história dos valores e, de maneira mais ampla, das representações - que podemos apreender o sentido fundamental do nascimento histórico da moda e seu posterior desenvolvimento.

A modernidade se definiria, antes de tudo, como uma ruptura na ordem dos valores. O A., examinando o modelo teórico das classes sociais, reconhece a ascensão social dos estratos burgueses desde o século XIV e a preocupação da aristocracia em resguardar sua posição hierárquica e criar meios que assegurassem sua distinção social. Esta mobilidade que verificamos nas relações sociais explicaria, em parte, as contínuas variações que se instalam nos vestuários de cada pólo da oposição: inovação aristocrática, imitação burguesa, difusão da novidade, outra inovação aristocrática e assim sucessivamente. Neste esquema só ocorre inovação porque a anterior deixou de sêtlo e, portanto, deixou de funcionar como elemento diferenciador. No entanto, a difusão que apagaria as marcas distintivas não seria suficiente para explicar muitas variações ocorridas: há, com frequência, inovações que surgem antes mesmo que outras tenham se difundido em meios sociais diferenciados. Constataríamos, assim, que a inovação não é concebida unicamente para distinguir e deveríamos relacionála, segundo o autor, a um valor específico da modernidade: o ideal e o gosto das novidades, "próprios das sociedades que se desprendem do prestígio do passado" (p.54). Existiriam, portanto, variaçōes sem significação nas relações sociais. 
Outro modelo explicativo põe em evidência os conflitos de prestígio entre os estratos dominantes das classes sociais e teríamos assim concorrência entre nobreza de toga e nobreza de espada, entre nobreza de corte e nobreza provincial, que representaria outra chave para compreensão dos movimentos da moda. No entanto, pode-se observar: são as pessoas que ocupam o topo das relações hierárquicas - reis, rainhas, princesas, princípes, grandes senhores - aquelas que produzem as variações e são imitadas, justamente estas que não teriam preocupação em distinguir-se, uma vez que estariam fora das questões de ascensão social. O problema que devemos compreender aqui são os motivos que levariam a alta hierarquia a afastar-se das referências e finalidades anteriores. Finalmente, deveríamos considerar a falta de explicação, a partir do esquema da classe social, para o fato de que a busca de uma expressão pessoal caracterize fundamentalmente a moda - se se trata apenas de ostentar as marcas distintivas do grupo ou classe social como entender a intensa preocupação com a demarcação de uma individualidade?

A conclusão que devemos tirar destes argumentos seria a seguinte: o conflito entre classes sociais, ou de uma maneira mais ampla, a referência da moda às relações sociais historicamente estabelecidas, pode explicar o movimento de difusão de uma novidade mas não a expressão da individualidade, nem a origem da inovação e o afastamento da tradição que ela implica.

Poderíamos, talvez, acompanhar topicamente os argumentos do A. e avaliar, por exemplo, a proposta não inteiramente explicitada, segunda a qual devemos considerar as motivações pessoais de um rei ou grande senhor para produzir uma inovação e tomálás como explicação da origem da variação. No entanto, a primeira observação a fazer ao enfoque proposto é a separação drástica, que está na base de sua formulação, entre práticas e representações na explicação de fenônemos sociais. O problema básico surge quando associamos, na forma proposta, o surgimento de uma prática como a moda a valores como os apontados: claro está que apenas deslocamos a questão do surgimento histórico da moda para o nascimento histórico destes valores. A renovação dos estudos sobre moda é uma necessidade, no entanto, os modelos propostos devem trazer um equacionamento mais fundamentado das relações entre práticas e representações (e nem desconsiderar a bibliografia existente sobre o tema). Quando nos referimos às diversas mudanças ocorridas na Europa durante os séculos XIV e XV, certamente não devemos minimizar as transformações nas relações sociais marcadas por uma maior mobilidade social. A moda e os valores a ela associados não podem ser entendidos fora dos quadros de relações sociais de um novo tipo que então ganha impulso.

Todo o problema retorna quando o A. analisa a moda dos cem anos vinculando as questões referentes à industrialização e aos inícios das sociedades de consumo de massa exclusivamente a tranformações na ordem dos valores. Segundo argumenta, se a roupa de moda torna-se um produto no mercado capitalista e, portanto, enquanto mercadoria tende à uniformização e à homogeneização, contrariando sua própria economia interna baseada na atividade de criação, podemos observar que também ocorre uma democratização da moda em função do enfraquecimento de determinados valores tradicionais e ascensão de valores democráticos. 
De fato, observa-se na Europa a partir da segunda metade do século $X I X$ e intensificando-se no século XX, a crescente difusão social da moda em vestuário, seu uso por outras camadas sociais antes sem acesso a este tipo de roupa. Mas este fenônemo deve ser exṕticado, segundo o $A$., em função das três seguintes mudanças. A primeira seria constituída pelas transformções na própria alta costura. Uma simplificação do vestuário feminino de moda a partir dos anos 20 , com Chanel e Patou, tornou os modelos mais facilmente imitáveis, modificação fundamental que diria respeito principalmente ao que denomina amortecimento do princípio aristocrático do conspicuous consumption e que seria concomitante à ascensão do imaginário democrático da igualdade de condições. O luxo ostensivo concebido para marcar as distâncias sociais foi atenuado: os signos de distinção social não desapareceram mas foram reabsorvidos num luxo mais discreto /do tecido, do corte, da griffel.

O surgimento e a difusão das práticas esportivas seriam uma segunda mudança, um fator estético pois seu efeito consistiu sobretudo em uma significativa transformação na aparência das pessoas. Surgiu uma nova estética do corpo feminino - a mulher esguia, esbelta e em movimento, enfim a mulher moderna tornando importante a exibição do corpo. É neste ponto, especificamente, que no texto é pressentida a autonomia pessoal - afirma-se uma relação dos novos trajes com o universo individualista-democrático mas não se desenvolve o assunto - na expressão da individualidade através do corpo desnudado no qual desfizeram-se os artifícios da indumentária em favor do "corpo natural".

Uma terceira mudança no vestuário de moda é também remetida a mudanças nos valores estéticos e concorreria para a simplificaçăo do traje: a influência do despojamento estilístico presente na arte moderna. É amplamente conhecida a utilização de elementos de artes plásticas no trabalho de alguns famosos costureiros e aqui o $\mathrm{A}$. pode apontar certos paralelos entre traços formais de roupas da moda e obras artísticas (linhas retas, planos nítidos e angulares, contornos geométricos).

Mas é neste último item que os novos valores implicados na moda podem ser melhor analisados pois o paralelismo entre moda e arte moderna vai muito além da existência de traços formais uma vez que o costureiro atingiu um novo status social: sua posição subalterna em relação ao usuário deu lugar ao costureiro como artista moderno, um criador. Existiam já, desde o século XVIII, vendedores e vendedoras de modas mas cuja autonomia para inovação era bem restrita em relação àquela da qual disporia Charles-Frédéric Worth, fundador da primeira casa de alta costura, realizando-se apenas sobre os ornamentos e acessórios da toalete e nunca sobre o próprio traje.

Costureiro e artista não se aproximariam apenas no exercício de uma atividade criativa mas também quanto à sua nova forma de atuação e organização: a vanguarda. Explicaríamos porque é possível constatar um intercâmbio pessoal e profissional constante entre famosos costureiros e conhecidos artistas plásticos e porque encontramos na moda não só as mesmas lutas de tendências mas também a mesma lógica da revolução lé o ápice da idéia da inovação) e a mesma valorização do Novo, presentes no trabalho artístico.

Esta promoção social das pessoas que trabalham com moda, anterior à constituição das sociedades democráticas, está ligada a transformações na 
representação social da moda. Lipovetsky observa como à exclusividade de uma literatura crítico-moralista que só descrevia o vestuário em função de certos valores afirmados ou fustigados substituiu-se a hégemonia de um novo meio especializado em roupas de moda, as revistas ilustradas e uma nova dignidade da moda na literatura (Balzac, Baudelaire, Mallarmé, Proust). O que significaria este processo? Segundo o A., trata-se da ascensão de duas paixões democráticas: o superinvestimento em questões relacionadas ao parecer e um interesse sem precedentes pelas novidades, ligadas a um fenônemo de maior alcance, a valorização das frivolidades - comer, fumar e outros assuntos considerados menores.

A reivindicação do status de arte para o ofício da moda constituiu também um esforço corporativista que fora antes desenvolvido por pintores, escultores e arquitetos mas no caso da moda ela fez-se segundo valores das sociedades democráticas: o ideal igualitário que se manifesta nas tentativas de afirmar para as roupas de moda a mesma qualidade nobre das obras da literatura e das artes plásticas e reivindicar o mesmo tratamento de que os artistas desfrutavam entre os nobres. Finalmente, uma nova moral individualista-hedonista, hegemônica nas sociedades modernas explicar-nos-ia para além das reivindicações corporativistas as transformações na moda: ela teria feito recuar os valores heróicos da nobreza e as restrições religiosas cristãs relativas às frivolidades mundanas.

A., no entanto, poderia ter formulado com mais acerto seus problemas. Ele não se furtou à análise de aspectos das transformações sociais envolvidas nestes problemas mas foi obrigado a arrolá-los como condições que explicam tenuamente a origem da moda e não forças que impulsionaram efetivamente seu aparecimento histórico. No caso da moda, nos séculos XIV e XV ele preocupou-se com a reflexão sobre um terceiro valor associado a ela e que a caracteriza de forma mais completa como expressão da cultura moderna - a nova importância do mundo "sensível": a moda em vestuário implica lidarmos com a materialidade da roupa, o que expressa uma ruptura fundamental que impulsiona a modernidade: a legitimidade da ação do homem sobre o mundo terrestre.

O problema começa a ser formulado na crítica e na retomada que se faz dos temas de Veblen. Sua obra representaria um terceiro e mais acabado modelo de explicação em termos de relação de classe no interior do qual, através da noção de consumo conspícuo, a moda é relacionada ao luxo ostentatório que demarca a honorabilidade social daquele que pode mantê-lo. Este enfoque recebe uma análise mais prolongada porque dele, conforme argumenta o A., poderíamos extrair uma conseqüência máxima destes modelos e ao mesmo tempo entrever uma característica fundamental da moda, até então obscurecida. Veblen caracteriza toda moda como essencialmente "feia", uma vez que produz um acúmulo de inovações não funcionais, concebidas apenas para exibição. Na perspectiva deste sociólogo, a dimensão estética da moda seria muito "reduzida" ou "inexistente". Esta conclusão inaceitável, segundo Lipovetsky, não nos deve fazer abandonar o conceito de consumo conspícuo. A dificuldade surge porque Veblen não deu atenção suficiente ao problema do luxo. Este supõe uma aplicação intensa sobre os elementos físicos dos objetos - forma, cor, matéria-prima, etc. - na busca da exibição visual das diferenças e hierarquias estabelecidas e a partir do século $\mathrm{XIV}$, o luxo encontrou na moda um largo campo para seu desenvolvimento. Aqui as relações sociais insinuam-se novamente na formação dos movimentos da moda. 
A ostentação de luxo tornou-se necessiclade fundamental para a nobreza européia a partir do século XIV quando seu prestígio social e poder político começaram a experimentar um acentuado refluxo, obrigando-a aos "gastos suntuários de representação", a uma acirrada luta em torno de signos distintivos.

Referimo-nos então à formação das sociedades de corte como forma de encaminhamento dos conflitos entre estratos da burguesia, da nobreza e monarquias. No entanto, estas transformações sociais e políticas não podem darnos a inteligibilidade da moda mas apenas do encontro moda/luxo, que acentua os efeitos estéticos que a primeira deve fornecer. As "condições sociais de emergência da moda" são, então, a noção esboçada pelo A. para evitar as interpretações mecanicistas e deterministas em análise social mas ao preço de "separar" definitivamente relações sociais e produção de sentido (neste caso, especificamente, de valores culturais).

Com relação à moda industrializada do século XIX, ele também não deixa de considerar as transformações econômicas e sociais que conformam um novo período para a moda em vestuário. A partir desta época, a roupa, antes um objeto de fabricação artesanal e doméstica muitas vezes apenas para consumo próprio e não para comercialização, passa gradativamente a transformar-se num produto industrial: primeiramente (por volta dos anos de 1820) as roupas que não eram de luxo na confecção industrial e posteriormente (a partir de 1857/8) as roupas de luxo que passaram a constituir a alta costura. Estabelece-se, de um lado a produção limitada de artigos de luxo diferenciados e, de outro, a produção massificada de artigos comuns padronizados. (Ao longo do tempo, a confecção industrial atingiria um patamar de diversificação dos produtos; dado o confínuo progresso tecnológico que experimentou, no entanto, até bem recentemente os modelos eram fornecidos pela alta costural.

Trata-se, portanto, da transformação da roupa de moda em mercadoria na sociedade capitalista. $\mathrm{O}$ A. define a alta costura como uma empresa de criação e de espetáculo publicitário. A partir de Charles Worth a roupa de moda constitui um produto comercializado por uma empresa, um artigo oferecido a clientes e não encomendado e definido pelo usuário ao qual olal costureiro(a) atendia. Os modelos são concebidos pelo costureiro, posteriormente apresentados aos clientes e executados sob medida após escolha. E a roupa de moda é comercializada segundo uma nova técnica que começava a desenvolver-se, a publicidade, esse o sentido da inovação na apresentação dos modelos: em desfile de mulheres jovens portando as roupas de luxo (inicialmente denominadas "sósias", mais tarde manequins).

Concebida como empresa, a confecção de roupas de moda estabelecerá seu ritmo de criação e apresentação, ou seja, de produção e circulação, segundo interesses comerciais: o A. mostra-nos como as datas de apresentação sazonais linicialmente apenas verão e inverno e depois incluindo outono e primavera, a meia-estaçãol tornaram-se fixas em função das exigências dos compradores profissionais estrangeiros a partir da intensificação do comércio internacional após a Primeira Guerra Mundial. A organização comercial da alta costura já tornava pouco antes, nos anos de 1908/10, os desfiles em apresentações espetaculares com horários fixos nos salöes das grandes casas. 
Estruturada segundo os novos padrões industriais, a moda em vestuário tenderá a anular as incertezas que poderiam prejudicar a comercialização: as contínuas mudanças nas roupas, que caracterizam o vestuário de moda, não experimentarão uma aceleração, como se acredita comumente, mas uma regularização: a um ritmo aleatório e a um certo fortuito na origem das inovações impuseram-se o ritmo regular e a especialização na criação lexclusiva agora do costureiro).

O surgimento da alta costura - comercialização empresarial da roupa feminina de luxo - acentuou uma certa unificação do traje europeu que se esboçava desde o século XVIII mas que até então mantinha significativas diferenças de caráter nacional. A alta costura francesa, articulada à confecção industrial, expandindo-se para outros países e difundindo-se para outras camadas sociais de menor poder aquisitivo, viria também a constituir um produto de consumo de massa, elaborado em série e padronizado.

Nenhuma destas transformações na produção do vestuário é convocada pelo A. para dar-nos a inteligibilidade do fenônemo moda. A roupa de moda, enquanto mercadoria, constituiria apenas um obstáculo à realização do potencial democrático da moda e não poderia constituir explicação para a vinculação desta aos valores modernos do novo e da individualidade.

Como se percebe, apenas arroladas para explicar a importância da dimensão estética da moda, as condições sociais e culturais não podem constituir fatores que expliquem a origem histórica da moda. Estranhamente, tais condições são dispensadas da explicação fundamental do fenônemo, consistindo apenas numa espécie de receptáculo passivo que dá ao fenônemo uma localização de tempo e lugar mas não constituem, em nenhum momento, as forças que atuaram para seu aparecimento. Partindo de uma má colocação do problema da moda, numa concepção que desarticula práticas e representações, Lipovetsky, ainda que ponha em evidência no seu trabalho a importância do "sensivel" na organização social, perde a oportunidade de elaborar uma proposta de encaminhamento para a análise das dimensões materiais da moda como fenônemo social.

\section{SOUZA, Gilda de Mello e. $O$ espirito das roupas: a moda no século XIX. São Paulo: Companhia das Letras, 1987, 255p., il. (FSM ECA/USP, HIS/USP, FE/USP, FIL/USP, MP/USP)}

Este livro é a publicação da tese defendida pela A. em 1951. Ele conta com um apêndice, no qual a $A$. discorre sobre o rapé, um produto muito utilizado no século XIX, e duas peças de indumentária feminina, o xale e o colete (espartitho); e mais uma sequência de 36 fotos, cujas legendas identificam tipos característicos da época: fazendeiros, militares, estudantes de direito, jovens senhoras, etc. Ressaltem-se também os cuidados de edição no intuito de atingir um amplo público e contemplar um tipo de obra na qual visualizar os objetos em questão, no caso a indumentária, é fundamental: assim, o texto é inteiramente acompanhado por imagens e estas por comentários em destaque ao pé das páginas, que não só ilustram mas explanam ou sintetizam todos os assuntos discutidos.

O estudo desenvolve-se em torno de dois assuntos principais. A diferenciação sexual acentuada no século XIX, plenamente observável no vestuário 
de homens e mulheres e oportunidade para a A. explicar a "cultura feminina", relacionando o investimento na indumentária para fins de sedução a práticas sociais como a exclusão da mulher do mundo do trabalho (confinando-a ao trabalho domésticol e realização pessoal apenas por intermédio do casamento; e o engate da moda com as questões de mobilidade social, processo intensificado com as transformações sociais daquele século. $O$ instigante capítulo final sobre a "festa" como fato social, constituindo-se na "grande fantasia" da aproximação - entre homens e mulheres e entre classes sociais - recolhe toda a análise anterior, encaminhando o estudo da indumentária como uma excelente estratégia de análise das sociedades democráticas.

Seu trabalho é significativo ainda hoje, em primeiro lugar porque constitui-se numa das poucas pesquisas acadêmicas brasileiras sobre moda e vestuário publicadas e, em segundo lugar, porque desenvolve entre nós os termos do debate iniciado ainda no século XIX, promovido por sociólogos e antropólogos em torno da moda, cuja definição conceitual deve buscar localizá-la num ponto intermediário entre os costumes e as manias.

O costume definiria, então, aqueles comportamentos que tendem à permanência e que, portanto, ligando-se preferencialmente à tradição, impōemse coercitivamente ao indivíduo (conforme Gabriel Tarde, Steinmetz, Sapir); a moda caracteriza-se também como um fenônemo coletivo que age coercitivamente sobre os indivíduos, mas suas mudanças são mais freqüentes e nela se introduz 0 problema das escolhas pessoais, posto que possuindo uma dimensão estética implica a questão do gosto (uma modulação individual sujeita à aprovação coletival; as manias - fads, crazes e hobbies - são variações ocorridas no interior de pequenos grupos e estando mais sujeitas ao gosto, exercem sua força de imposição de maneira muito localizada e fluida, podendo mesmo perdê-la completamente pois a "extravagância" suscita frequentemente a desaprovação coletiva - não podem, como a moda, caracterizar uma sociedade e nem mesmo uma classe social.

Nesta perspectiva a moda é um fenônemo significativo para análise social por estar referida à organização da vida social e não só às especificidades da vida individual. Suas características são compreensíveis considerando-se seu papel mediador nas relações entre grupos e classes sociais e deve-se, enfim, apreendê-la em sua eficácia coercitiva. Por isso, podemos entender porque neste estudo o surgimento da moda está vinculado a dois fatores: desejo de competição e hábito da imitação (que ganharam força na Renascença com as novas condiçōes postas pelo desenvolvimento do espaço urbano e da vida nas cortes: a proximidade espacial entre pessoas). O significado da moda não é apreendido nos problemas relativos à origem da inovação mas, preferencialmente, no movimento de sua difusão.

O esquema da moda funciona livremente no século XIX. Na constituição das sociedades industriais e democráticas, com $\odot$ fim das barreiras políticas e jurídicas à ascensão social, a competição instaura-se plenamente e a moda pode realizar-se em toda a sua potencialidade, acelerando a velocidade de suas variações e a sucessão dos estilos. Mas se a competição entre grupos e classes sociais é o fator que impulsiona a moda, os comentários sobre a Renascença revelam que no núcleo da competição estaria não tanto o interesse em distinguir-se mas a preocupação em imitar. A competição se lançam os grupos em ascensão 
social que passam a copiar as inovações surgidas naqueles de maior domínio e prestígio na hierarquia social.

Este enfoque parece levar a uma concepção restrita, por exemplo, do significado das leis suntuárias (que prescreviam o tipo de indumentária permitida a cada categoria sociall. Estas leis são tomadas pela autora como tentativas infrutiferas de uma sociedade de ordens em manter-se como tal, simples formalidades que sobrevivem, apesar da expansão de práticas sociais que the são contrárias. O problema a ser compreendido seria o abrandamento destas leis, concebidas para restringir os grupos sociais participantes do jogo da moda mas tornadas ineficazes conforme a riqueza, ao longo do tempo, supera a condição de nascimento como critério de prestígio na hierarquia. Na verdade, seria preciso compreender a permanência destes dispositivos legais, aplicados com maior ou menor eficácia - situações que uma pesquisa histórica necessitaria esclarecer - por um período tão longo (pelo menos do século XIV, época de seu intenso reforço, até o século XVIIII, mesmo sob formas de organização social tão diferenciadas.

"gosto" aparece, então, como obstáculo à compreensão da moda. Steinmetz estabelece como procedimento fundamental na metodologia de análise a observação empírica do exercício da moda (devemos examiná-la com "nossos próprios olhos"). A A. procura afastar-se da proposta e aponta como dificuldade a restrição do pesquisador à observação do gosto, que não poderia nos revelar as linhas essenciais do desenvolvimento da moda mas apenas fornecer-nos as justificativas dos agentes e não suas motivações mais profundas para a adoção de uma dada inovação. Distinção pertinente entre processo sociais e a consciência que se pode ter deles, mas que descarta o exame dos elementos físicos - cores, matérias-primas, formas - e minimiza a análise da dimensão estética das roupas e as mediações entre individual e coletivo implicadas na moda lembora explicitamente consideradas).

A A. enfatiza a complexidade do fenônemo e as dificuldades para seu estudo: "serve à estrutura social, acentuando a divisão em classe; reconcilia o conflito entre o impulso individualizador de cada um de nós (necessidade de afirmação como pessoa) e o socializador (necessidade de afirmação como membro do grupo); exprime idéias e sentimentos, pois é uma linguagem que se traduz em termos artísticos. Ora, esta expressão artística de uma linguagem social ou psicológica - o aspecto menos explorado da moda - talvez seja uma de suas faces mais apaixonantes" (p.29). Contudo, mais adiante afirma: "No entanto, se cada vez que o estilo varia a moda cai sob o domínio da arte, o que explica a mudança?... Esta pergunta quem a responde, a nosso ver, não é mais a Estética e sim a Sociologia" (p.51). Faz-se aqui uma opção mas estabelecendo uma dicotomia entre análise estética e abordagem sociológica. Uma formulação que deixa escapar o problema da materialidade mesma de um objeto - as roupas - na formação, desenvolvimento e mudança de relações sociais.

Não se trata, como podemos verificar nos trechos citados, da desconsideração de qualquer significado social do vestuário mas sim de conceber a subordinação da estética da indumentária às transformações ocorridas no contexto social (relações políticas, econômicas, estratificação de classes). No entanto, as análises desenvolvidas no livro superam estes enunciados gerais e apontam para outras direções de pesquisa. No exame do pronunciado antagonismo entre os 
papéis masculino e feminino estabelecido no século XIX, é nas formas, nas cores e nos tecidos que podemos verificar tal distinção, materialmente assegurada, e percebermos como uma dada forma de organização social las sociedades democráticas) conformam as dimensões físicas da indumentária. No exame das diferenciações de classe há passagens muito sugestivas, como aquelas referentes às modificações nas saias entre os anos 1850-1880. Constatamos que a saiabalão e a crinolina atingem seu volume máximo, tolhendo a capacidade de movimento de suas usuárias, num momento em que a tecnologia do transporte - é a época dos trens - ganha um forte impulso; em seguida, abandonada a preocupação com os volumes, surgem as caudas, longas que têm o mesmo efeito de não facilitar a movimentação; e mesmo uma mudança mas significativa como - aparecimento, nos anos de 1880, das saias justas, com inúmeros adereços, que dificultam até mesmo $o$ ato de sentar.

Estas constatações, ligadas às considerações de Veblen sobre o consumo conspícuo (p. 125), levaram a A. à seguinte conclusão: "Como se vê, a moda tanto pode refletir as transformações sociais como opor-se a elas através de inúmeros subterfúgios, todas as vezes que há perigo de uma aproximação excessiva entre as classes e os sexos" (p.129). As transformaçōes sociais seriam a característica dominante das sociedades democráticas do século XIX, e esta "oposição" que a roupa pode fazer ao seu próprio "tempo" deixa entrever outras dimensões sociais do vestuário. Aqui ele se apresenta como um verdadeiro dispositivo material que conforma os movimentos físicos do indivíduo, mobilizando o corpo na efetivação "concreta" das relações sociais. Quase nos deparamos nestas considerações acima com o problema dos suportes sensiveis que as relações sociais necessitam para realizar-se.

Uma revisão minuciosa deste trabalho poderia demonstrar que a dificuldade que impediu a formulação do problema encontra-se no campo mesmo de opções em que se colocou a A., discutidas a propósito da questão da roupa de moda considerada como criação artística (capítulo 2). Afirma, então, sua preferência pelo método da "ligação das coisas simultâneas" defendido por Taine, em detrimento da concepção de "espírito do tempo" que se encontra em James Laver ou G. Heard. Ambas as posições, no entanto, supõem constatar um paralelismo tanto no âmbito das artes (pintura, escultura, arquitetura, etc.), quanto no âmbito dos objetos (indumentária, objetos de interiores, etc.) muito duvidoso em alguns casos $\mid G$. Heard refere-se à predominância das formas cilíndricas no século XIX: a cartola é cilindrica, o túnel e a chaminé também o são). A consequência de uma tal colocação é a preocupação com o elemento comum que estaria presente em todas as manifestações sociais e materiais de um determinado período, em detrimento do caminho mais frutífero de pensarmos as formas de articulação de atividades sociais diversas, ou de forma mais precisa, dos diferentes níveis da organização social (econômico, material, político, ideológico, imaginário).

\footnotetext{
ABREU, Alice Rangel de Paiva. Avesso da moda: trabalho a domicílio na indústria de confecção. São Paulo: Hucitec, 1986, 302p. (ESALQ/USP)
}

Este trabalho é a publicação da tese de doutoramento defendida pela A. na Faculdade de Filosofia, Letras e Ciências Humanas da USP, em 1980. 
fítulo dá bem a entender o interesse que encerra para os estudos sobre vestuário pois o enfoque recai em área pouco contemplada em textos para um público não especializado, a produção de roupas de moda, o que conhecemos hoje como confecção industrial. A pesquisa consiste em duas partes: numa introdução sobre o desenvolvimento do trabalho industrial a domicílio desde a Revolução Industrial, especialmente na indústria de confecção; e na análise de uma série de 53 entrevistas realizadas com operárias de fábrica, costureiras internas lempregadas nas oficinas de confecção) e costureiras externas (mulheres contratadas pelas oficinas mas que trabalham no próprio domicíliol. Trata-se de um estudo em sociologia do trabalho no qual analisa-se a estrutura do emprego feminino e as condições de trabalho num setor específico da indústria de confecção brasileira: as oficinas de confecção de roupa feminina de alta qualidade (vendidas apenas em butiques), na cidade do Rio de Janeiro.

Seu valor para o debate sobre as formas de organização da economia contemporânea, vale dizer para a compreensão dos mecanismos de reprodução do capital, é amplamente reconhecido no prefácio de Heleieth Saffioti. Neste aspecto o ponto principal é a persistência daquelas atividades econômicas que escapam às regulamentações legais, comumente denominadas setor "informal" ou "invisível" da economia e nelas do trabalho a domicílio. Este último é o objeto de interesse da A.. Seguindo os estudos de E. Thompson, demonstra como ná primeira fase da Revolução Industrial (1780-1840) constitui a forma predominante; apenas na indústria têxtil o sistema fabril implantou-se fundamentalmente /sobretudo na produção de algodão e lã). A constituição do mercado de trabalho capitalista não teria se dado, então, pela passagem do artesão independente para o operário de fábrica, mas predominantemente pela subordinação do trabalhador industrial a domicilio aos interesses do capital. Os efetivos globais do trabalho a domicílio. subordinado à produção industrial diminuíram desde a segunda metade do século XIX mas este não desapareceu. As estatísticas que a $\mathrm{A}$. pode trabalhar ao longo do século $X X$, tanto para os países altamente industrializados, quanto para os países da América Latina, sobretudo para o Brasil, demonstram a importância dos setores informais e neles, do trabalho a domicílio para a produção econômica.

A persistência desta forma de organização do trabalho deve-se à sua utilização como forma de diminuir os custos com o fator trabalho. Observa-se que ela se enfraquece em determinados períodos quando é alcançada por regulamentações legais, principalmente aplicação de direitos trabalhistas que encarecem sua remuneração (são exemplos as Trade Boards da Inglaterra, no início do século, e a legislação italiana de 1973). É esta característica que faz com que a partir dos anos 60 muitos pesquisadores latino-americanos, incluindo os brasileiros, a analisassem como forma estrutural da organização econômica capitalista nos marcos de uma discussão sobre o desenvolvimento econômico desigual e combinado, à qual a $\mathrm{A}$. vem trazer sua contribuição.

Ocorre que se o interesse econômico pode explicar satisfatoriamente este aspecto da organização estrutural da produção capitalista, a organização da produção e do trabalho na indústria de confecção só são compreensiveis quando analisamos a articulação do objetivo econômico de maximização dos lucros da empresa capitalista com valores culturais. São fatores culturais da organização econômica que transparecem nos argumentos desenvolvidos pela 
A., aos quais ela, por vezes, atribui peso na discussão, aspecto também observado pela prefaciadora que faz referência ao que denomina "diferenciação extra-econômica na massa de trabalhadores", dando relevância aos aspectos ideológicos e políticos na dominação econômica.

A A. apresenta-nos quatro características específicas da indústria de confecção: baixo impacto de inovações técnicas; heterogeneidade da estrutura industrial; alta divisibilidade do processo de produção; fundamental importância da atividade de comercialização, sobretudo de marketing. Estas características mais o processo de feminização do trabalho a domicílio, discutido no texto, só podem ser compreendidos na análise dos valores culturais envolvidos na produção industrial do vestuário, a saber, aqueles oriundos da divisão sexual do trabalho que depreciam o trabatho feminino e aqueles que aprofundam as diferenciações entre as identidades de homem e mulher.

A utilização do trabalho de mulheres, crianças e outros grupos como imigrantes constituem desde o século XIX um fator de barateamento de mão-de-obra pois sua remuneração sempre foi menor do que aquela estabelecida para homens adultos. Após a Primeira Guerra a A. mostra-nos como o trabalho feminino transformou-se no principal fator de economia nos custos do trabalho, justamente porque o trabalho a domicílio foi mantido principalmente nas indústrias que tradicionalmente empregavam mão-de-obra feminina, como aquelas de confecção de vestuário feminino e de chapéus (não é acaso que os vários estudos contemporâneos sobre estrutura do trabalho feminino utilizados pela $A$. são também estudos sobre a indústria de confecção). Sua pesquisa no mercado de trabalho brasileiro demonstra os mesmos objetivos para o emprego de mão-de-obra feminina, mostrando seja a subcontratação de costureiras externas fora do regime de CLT (Consolidação das Leis do Trabalho), seja a fraca posição das costureiras na negociação dos valores a serem pagos pelos serviços, ou ainda, a aplicação de uma política de rotatividade de mão-de-obra que pode ser inferida a partir da constatação de que a mobilidade profissional das costureiras é predominantemente horizontal (mudança de emprego) e não vertical (ascensão a postos melhor remunerados numa mesma empresa).

Esta função do emprego feminino nos custos do fator trabalho explica-se pela persistência da divisão sexual do trabalho nas sociedades industriais, que deprecia a remuneração do trabalho da mulher ao considerálo "complemento" do trabalho masculino. Se esta situação é apontada em trabalhos sobre a Revolução Industrial, a A. pode observáta no estudo de caso que desenvolveu. Compreender as diferentes formas de inserção das costureiras no mercado de trabalho da indústria de confecção implica considerar o papel da mulher na família e, de fato, a A. pode demonstrar como "os vínculos com as responsabilidades domésticas em distintas etapas do ciclo familiar vão influenciar o tipo de participação no mercado de trabalho".

As tarefas domésticas sendo responsabilidade das mulheres tornam o trabalho assalariado uma opção em momentos de prementes necessidades financeiras. Assim, o trabalho como costureira interna numa fábrica, implicando trabalho fora do lar, aparece como complemento da renda familiar nos períodos nos quais o marido não pode sozinho sustentar as despesas domésticas ou quando elas próprias eram obrigadas a prover o sustento (quando viúvas ou separadas). 
Já o trabatho a domicílio aparece como uma forma de trabalho remunerado que não perturba significativamente as atividades domésticas e é inclusive mais aceito pelos maridos (em geral há conflitos com estes) e permite também um acréscimo na renda familiar para atender a necessidades importantes em diferentes períodos do ciclo de vida tamiliar (construção da casa própria, despesas com os filhos).

A costura externa permite uma flexibilidade na organização do trabalho, que possibilita à mulher ocupar-se de suas atividades domésticas mas isto de uma maneira especial pois realizar as tarefas aí implicadas significa cumprir suas obrigações de dona-de-casa e, portanto, desempenhar seu papel de mulher. A alocação dos recursos financeiros da família é realizada também segundo as obrigações próprias do marido e aquelas da esposa. $O$ salário da mulher é empregado em itens específicos como a complementação da alimentação diversificando os itens da cesta básica da família. Assim explica-se a ocorrência deste tipo de trabalho industrial a domicílio pela possibilidade de manutenção de, nos termos da $A$., um padrão ideal de distribuição de tarefas entre homens e mulheres das classes trabalhadoras (respectivamente trabalho remunerado e trabalho domésticol e as "correções" sistemáticas que sofre diante das necessidades de complementação da renda familiar.

A pesquisa indica, portanto, que a possibilidade de manter a divisão sexual do trabalho torna o trabalho industrial a domicílio receptivo às classes trabalhadoras. Quanto às diferenças entre as identidades de homem e mulher, é sabido que no início do século XIX acentuaram-se as diferenças formais entre os trajes masculino e feminino, este com uma quantidade muito maior de elementos decorativos e submetido a variações sazonais que caracterizam a moda em vestuário, ao contrário do primeiro, experimentando um menor número de variações e menos submetido às mudanças da moda. De uma forma geral considera-se a roupa masculina simples e a feminina complexa. É sabido também que estes dois padrões diferenciados de vestuário estão referidos à construção da identidade masculina e da feminina, em acentuada oposição segundo os papéis atribuídos a cada um no mundo social do trabalho e mundo privado do espaço doméstico. É pouco conhecido, no entanto, o quanto a organização da produção e do trabalho na indústria de confecção - considerando suas três primeiras características apontadas anteriormente - estrutura-se em função da construção da identidade de homem e de mulher.

O vestuário masculino, simples e experimentando poucas variações no padrão, não apresenta dificuldades técnicas de produção e cria uma demanda estável que permite a estandardização dos produtos e os ganhos de escala, suportando os custos de uma estrutura administrativa para controle do trabalho parcelado; o feminino, ao contrário, complexo e extremamente variável no padrão, apresenta muitas dificuldades técnicas de produção e estabelece uma demanda instável que não permite a estandardização dos produtos e os ganhos de escala. A lucratividade na produção de roupas femininas está na flexibilidade da empresa em atender as contínuas modificações na demanda e na aplicação do fator trabalho, eliminando-se despesas com estrutura administrativa.

Quanto à quarta característica da estrutura da indústria de confecção, a divisibilidade das tarefas e o monopólio das atividades de criação, preparação (modelagem e corte) e comercialização dos produtos, destacando-se nesta última 
o investimento em marketing, sua discussão é um pouco mais desenvolvida no capítulo 3, no qual utiliza-se entrevistas com proprietários de oficinas de confecção para compreender com maior detalhe a organização das empresas. Verifica-se que devem ser flexíveis quanto à produção para responderem de maneira rápida às constantes mudanças na demanda. Estruturam-se como empresas de pequena e médio porte, em geral com uma produção de duas mil a cinco mil peças $/$ mês, através de uma equipe interna de vinte a trinta pessoas; que centraliza as atividades indicadas acima e ao mesmo tempo contratam costureiras externas para a fase de produção, reduzindo os custos de capital fixo e mão-de-obra.

O sucesso dos empreendimentos no setor depende em muito do que poderíamos chamar "capital cultural". A experiência administrativa e a capacidade de gestão financeira são requisitos para a boa condução das empresas mas a inventidade na criação e a sensibilidade para perceber os modelos de maior demanda numa estação (diagnosticar tendências) são exigências que determinam o sucesso ou fracasso de uma tentativa. Entre as empresárias, exclusivamente, constata-se que muitas vezes começaram com um capital muito baixo e sem nenhuma experiência empresarial mas cujo sucesso podemos explicar através do conceito de habitus elaborado por Bordieu pois observa-se que suas relações sociais e seu circuito de estudos e viagens as aproximam do público cuja demanda procuram atender.

O estudo da industrialização pelo sistema fabril da confecção de roupas nos países desenvolvidos mostra todas essas características do setor. A produção de vestuário pelo sistema fabril iniciou-se nos anos de 1880 e já desde meados do século surgiam inovaçães técnicas no setor, a mais destacada sendo a máquina de costura (primeira versão comercial em 1851), mas são transformações que ou aumentaram a produtividade do trabalho a domicilio ou ocorreram e fiveram aplicação em ramos específicos da indústria de confecção, calçados e roupas masculinas, mercadorias suscetiveis de padronização.

A produção fabril de vestuário feminino iniciou-se durante a Primeira Guerra, intensificando-se durante a década de 20. Transformações nos custos de mão-de-obra são um primeiro fator a considerar lexaminando o caso inglês, a diminuição da imigração judia durante a guerra e a regulamentação do trabalho a domicílio através de Trade Boards encareceram o custo desta forma de relação de trabalhol. Ao mesmo tempo, os custos com investimento em técnicas de produção haviam diminuído em relação a períodos anteriores com os aperfeiçoamentos das inovações já utilizadas na fabricação de roupas masculinas e então largamente utilizados na confecção de uniformes militares. Mas há também uma transformação no padrão formal do vestuário feminino que possibilitou sua produção em série nas fábricas. Ocorre uma simplificação da roupa de mulher durante a guerra que diminui os problemas técnicos para sua confecção, mudança que se torna padrão para as décadas seguintes e para a qual concorrem transformações em valores sociais /a decadência do princípio aristocrático do conspicuous consumption, nos termos de Lipovetsky).

Embora o sistema fabril tenha se introduzido em toda a indústria de confecção, a escala dos empreendimentos permaneceu pequena em relação a outras indústrias e o trabalho a domicílio continuou empregado de forma constante. Uma nova expansão do sistema fabril na confecção de vestuário ocorre com a 
eclosão da Segunda Guerra. Surgiram grandes fábricas de roupas femininas, de produção em larga escala, mas elas só se mantiveram no pós-guerra para aqueles produtos suscetiveis de padronização (jeans e roupas íntimas) permanecendo seu grau de desenvolvimento técnico comparativamente menor do que de outras indústrias leves como, por exemplo, a eletrônica.

O mesmo tipo de desenvolvimento experimentou a indústria de confecção brasileira. Quanto aos setores de maior produção, em 1920 a indústria de calçados e chapéus ocupava mais da metade da mão-de-obra empregada no. setor de confecção; na fabricação de roupas predominavam as roupas brancas ("internas"). Quanto as roupas "exteriores", as femininas e infantis eram tão inexpressivas que estavam incluídas na categoria "roupas para homens". Esta situação indica que boa parte da demanda era atendida pelo produtor independente, $O$ alfaiate e a costureira.

A partir da década de 1960 a roupa feminina tornou-se o produto de maior importância, superando a produção de outros setores. Desde então verificase um crescimento significativo das empresas de médio e grande porte e a heterogeneidade estrutural verificada para os outros países observa-se também no Brasil pois nas décadas de $1970 / 80$ as pequenas empresas constituíam $88,1 \%$ dos estabelecimentos e ocupavam $32,1 \%$ da mão-de-obra. A utilização de trabalhadores a domicílio continuou importante, pois na indústria de confecção constituem a maior parte do trabalho informal, para cuja relação com o trabalho formal alguns esłudos apontam os seguintes índices: em 1970, relação 1:3; em 1980 , relação $1: 1,54$.

\section{II - Lista Comentada}

ABREU, Alice Rangel de Paiva. Avesso da moda: trabalho a domicílio na indústria de confecção.

São Paulo: Hucitec, 1986, 302p.

(ESALQ/USP)

Vide acima, páginas 272-277

ALPARgatas. 80 anos de nossa bistoria. São Paulo: Edição de

Mauro Ivan Marketing Editorial, 1987, 87p., il. (SENAC)

Edição comemorativa patrocinada pela Alpargatas S.A., é obra que descreve a trajetória desta empresa, fundada em 1907 com capitais ingleses e escoceses e, então, especializada na confecção de calçados de lóna e encerados, mas que, ao longo do tempo, transformou-se em empreendimento exclusivamente brasileiro com produção diversificada, fabricando artigos esportivos, roupas como o jeans e manufaturados têxteis diversos.As ilustrações merecem destaque: além de fotos dos arquivos da empresa, o livro traz muitas imagens publicitárias, constituindo um importante conjunto para a história da publicidade da fábrica, sendo também de interesse, neste mesmo sentido, o registro de várias técnicas de marketing utilizadas por ela (promoção de shows artísticos, etc.).

ALVIM, Zuleika; PEIRÃO, Solange. Mappin 70 anos. São Paulo: Ex-Libris, 1985, 221p., il. (FAM, FAU/USP, FE/USP, MP/USP)

Obra comemorativa dos 70 anos da loja de departamentos, resultado da pesquisa encomendada às autoras. Utilizaram uma variada documentação, com destaque para as fontes orais - depoimentos de funcionários, exfuncionátios e clientes - es álbuns com anúncios comerciais organizados pela própria empresa. O material iconográfico selecionado para as ilustrações é particularmente rico pois além do acervo da empresa muitos colecionadores particulares cederam importantes imagens.

No relato sobre a origem e desenvolvimento da empresa, ressalta-se em diversos momentos os números impressionantes que acompanham a história deste empreendimento inicialmente inglês e desde 1950 de 
propriedade de brasileiros: o valor de seu patrimônio líquido, a movimentação de clientes, o volume de vendas, a eficiência administrativa, entre outros itens, a colocam entre os maiores do ramo no Brasil. Esta trajetória de sucesso do Mappin não é elaborada aqui apenas como a história de uma empresa paulistana mas sim como a formação de uma das "instituições" de São Paulo - comparável principalmente a outros marcos referenciais como o Viaduto do Chá - que constróem a identidade da cidade.

\section{BARROS, Edgard Luiz de. Passagens da moda. São Paulo: SENAC, 1993, 42p., il. (SENAC, IEB/USP,} MP/USP)

Obra de divulgação do Centro de Moda e Decoração do SENAC-SP.O autor é consultor do Centro e historiador. Seu ensaio inicia-se com a discussão de um dos principais problemas para a compreensão da moda em vestuário: a falta de reflexão teórica adequada para abordar um fenômeno central nas sociedades de consumo, situação agravada no Brasil pela falta de interesse institucional e social na preservação documental - museológica, iconográfica e textual - da produção de moda e pela escassez de pesquisas monográficas sobre o tema. Estas considerações doA. devem muito ao trabalho de Gilles Lipovetsky, seguindo-o inclusive na terminologia utilizada e na formulação dos problemas.

Após a introdução desta problemática, o A. faz um breve resumo da moda européia do século XV ao XX e da história da moda no Brasil do final do século XIX até os dias atuais, correndo o risco de elaborar uma narrativa que permanece à superficie dos processos, apenas registrando mudanças e retomando algumas explicações já consagradas mas pouco problematizadas. É o caso, por exemplo, ao fornecer as razões para mudanças verificadas no final do século XVII: "com o incremento da teatralidade e dos jogos de fantasia estéticos", o rebuscamento da indumentária, até então mais acentuado no traje masculino, passa a caracterizar apenas o feminino. Ora, se apresentarmos esta acentuação como a razão para a "fantasia estética" caracterizar apenas as roupas femininas, já aceitamos de saída a equação feminino = rebuscamento, quando é justamente esta nova identificação a mudança que exige explicação. Estamos muito longe do corte vertical e profundo para entendermos criticamente a moda tal como propõe lipovetsky.

BARROS, Fernando de, NAHYUM, Perla (Org). Sapatos: crônica de um tempo 1900-1991. São

Paulo: Francal, 1991, 56p., il. (MP/USP)

Publicação realizada em homenagem à Francal (Feira Nacional de Calçados e Artefatos), em sua $23^{2}$ edição, reúne pequenos textos de especialistas e profissionais nas áreas de moda, vestuário e comunicação, nos quais esboça-se alguma análise ou veicula-se determinadas opiniōes sobre o uso e os significados dos calçados. Estão dispostos de tal maneira que se apresenta a história moderna dos calçados compreendendo, sobretudo, o período $1920 / 1980$.

BARTHES, Roland. Sistema da moda. Tradução por Lineide do Lago Salvador Mosca. São Paulo: Editora Nacional/EDUSP, 1979, 301p. (FD/USP, LET/USP, FSM, MP/USP)

Vide acima páginas 248-254

BASILE,Aissa Heu \& LEITE, Ellen Massucci. Como pesquisar moda na Europa e EUA. São Paulo: Senac, 1996, 196p. (SENAC)

Guia bastante especializado, voltado para os profissionais de moda que viajam a trabalho para a Europa e EUA. Traz indicações sobre os cuidados para organizar uma viagem de serviço mas fornece, principalmente, informações sobre as lojas e os locais (as relações incluem também mercados de pulgas, livrarias, hotéis, bares da moda, etc) mais importantes para conhecimento das tendências de moda em quatro cidades: Paris, Londres, Milão e Nova York. Para oferecer a possibilidade de montagem de roteiros pessoais o livro apresenta a descrição dos lugares referenciados, a linha de produtos de cada qual e, atendendo à praticidade que se espera deste tipo de publicação, a rubrica $\mathrm{Dica}(s)$ com dados específicos sobre cada localidade que podem facilitar o trabalho do profissional.

BOLLON, Patrice. A moral da máscara: Merveilleux, Zazous, Dândis, Punks, etc. Tradução por

Ana Maria Scherer. Rio de Janeiro: Rocco, 1993, 236p., il. (FIL/USP)

A noção de estilo é central neste livro. OA., conceituado jornalista, a define como um investimento pessoal na aparência, que encerra uma ética "aberta", criadora de novos valores em épocas de transição. Os "movimentos de estilo" analisados - libertins franceses do século XVII, dândis do século passado,punks da nossa atualidade 
e muitos outros - revelariam que os comportamentos e modos de pensar considerados "fúteis", "superficiais", na verdade, questionam a ordem social e política estabelecida, criticam o senso comum e ensejam práticas de transformação social.

CARVALHO, Flávio de. Moda e o novo bomem. São Paulo:SESC/SENAC, 1992, 161p., il. (SENAC, MAC/USP, MP/USP)

Trata-se da reunião de artigos publicados por Flávio de Carvalho no jornal Diário de São Paulo entre março e outubro de 1956. A apresentação fornece os dados biográficos do A. e cita um dos eventos que mais o notabilizaram: em 18/10/1956 desfilou pelas ruas centrais da cidade de São Paulo com uma camisa amarela, saiote verde e sandálias, sua proposta de vestuário masculino para o verão daquele ano.

$O$ desfile coroava um pensamento sobre história da moda e natureza humana que o autor expunha em seus artigos.Argumentava que a moda deve ser compreendida na sua relação com um par antitético: estabilidade/ equilíbrio/repetição/sociedade - instabilidade/desequilíbrio/ criação/indivíduo. Sustentava, então, que dado o parco desenvolvimento cerebral e psicológico do homem, a moda é apenas potencialmente uma forma de expressão pessoal e só se realiza historicamente como um dispositivo de contenção do indivíduo para surgimento do vínculo social. Sua proposta é pensá-la enquanto possibilidade de superação das constriçóes sociais à criação pessoal. Por isso, a valorização do sonho e da loucura, consideradas radicais expressões de singularidade.

CENOGRAFIA e indumentária no TBC: 16 anos de história, 1948/1964. São Paulo: Secretaria de

Estado da Cultura, 1980, 157p., il. (ECA/USP, FAU/USP)

Esta obra é um catálogo da Mostra de Cenografia e Indumentária (sob supervisão, coordenação geral e pesquisa de José Armando Ferrara e José Carlos Serroni), parte do Projeto Cacilda Becker, um conjunto de atividades que tinha por objetivo revitalizar, a partir do ano de 1980, o Teatro Brasileiro de Comédia (TBC). Projetada como uma exposição que cobrisse os 32 anos de atividades no teatro (fundado em 1948) e que servisse de núcleo inicial a um Museu Teatral, ela restringiu-se, em função dos recursos humanos e financeiros então disponiveis, a maquetes dos cenários, desenhos dos figurinistas e fotografias dos atores em atuação (emprestadas de arquivos públicos e particulares) referentes aos primeiros 16 anos. É este material que compõe o catálogo e a partir do qual podemos observar aspectos dos cenários e indumentária utilizados. Está organizado segundo os figurinistas ou figurinistas/cenógrafos responsáveis, dos quais são fornecidos alguns dados biográficos.A obra contém ainda alguns textos de diferentes autores sobre a história, cenografia, repertório e trabalho nos bastidores do TBC e mais uma relação de seus atores, diretores e técnicos, bibliografia específica, glossário de termos cenográficos e desenhes ilustrando a evolução do espaço teatral, diversos detalhes técnicos e mais um planta genérica de palco.

CHATAIGNIER, Gilda. Todos os caminbos da moda: guia prático de estilismo e tecnologia. Rio de Janeiro: Rocco, 1996, 239p. (SENAC)

A A. é editora com larga experiência no jornalismo de moda, tendo atuado em jornais, revistas e televisão. $O$ guia que elaborou é bastante abrangente pois traz informações sobre os principais cursos e profissionais em todo o Brasil e nas mais variadas atividades ligadas à moda: desde aquelas da área de fabricação têxtil, passando pelo ensino das técnicas de confecção de roupas até as atividades de divulgação de produtos - jornalismo, organização de desfiles, montagem de vitrines em lojas, etc. O livro não se compõe apenas de listas de títulos e instituições mas sim de textos curtos e objetivos, algumas vezes fornecendo dados históricos sobre peças de roupa, equipamentos ou técnicas.

CONTINI, Mila: Moda: 5000 anos de elegância. Tradução por José V. de Pina Martins. S.l. Verbo, s.d., 318p., il. (FAU/USP)

A A. - uma jornalista italiana, segundo a introdução realizada pelo tradutor - compôs um vasto e fartamente ilustrado painel da moda em indumentária, do Egito antigo à Europa dos anos 1960. Seu texto mescla a crônica de acontecimentos políticos e econômicos com a descrição dos tipos de vestuário mais utilizados ou em destaque em cada sociedade ou período histórico abordados, às vezes relacionando características do objeto material e determinadas formas de organização social. Em diversos momentos, preocupou-se em valorizar a importância da atuação das mulheres na história (o que parece ter motivado as afirmações contrárias do seu tradutor), mas fora esta preocupação em desenvolver um novo viés na história da moda, apresenta-nos um trabalho que recolhe e organiza em ordem cronológica fatos e idéias bem conhecidos neste campo. 
DORFLES, Gillo. A moda da moda. Tradução por Teresa de Campos Coelho. São Paulo: Martins Fontes, 1984, 121p. (SENAC, MP/USP)

O A. avisa-nos desde o início que o tema deste livro é um tanto marginal em suas reflexões mas considera-o importante tanto na sua vida pessoal quanto na vida social. De fato, não se detém em considerações mais demoradas a respeito, compondo seu trabalho com vários e rápidos comentários, alguns sobre o fenômeno moda em geral, outros sobre aspectos que considera significativos em modas particulares.A respeito do problema que esperaríamos examinado - o especial interesse sobre moda na década de 80 - afirma sinteticamente que ele "se deve, essencialmente (como acontece com muitos outros fenônemos atuais), à convergência de aspectos estéticos com aspectos econômicos". Apenas vislumbra-se nesta afirmação a questão das transformações nos padrões de consumo nas sociedades altamente industrializadas do pós-guerra.

OA. define como seu objetivo demonstrar o valor da moda na atualidade.A.moda estaria a meio caminho entre o objeto de arte e o produto comercial - elaborada para fins de exibição e consumo imediato estaria menos sujeita a transformar-se num objeto de alto investimento financeiro, como as pinturas - e poderia constituir-se numa maneira de atualizarmos nossos juizos estéticos ainda baseados na idéia do "belo absoluto", aceitando a validade de fatores estéticos mais contingentes ("imediatos").Se razões utilitárias guiam as escolhas em roupas de moda, em detrimento de razões ideais, culturais ou morais podemos ainda assim encontrar um valor positivo da moda mesmo nas atuais condições de predomínio de interesses econômicos. OA. pode assim entrever um efeito educativo na publicidade extensamente veiculada pelas $T$-shirts (na difusão em masșa de tendências artisticas) ou um certo conforto na moda atual em comparação com a faustosa mas pesada indumentária seiscentista (aí incluídas as armaduras!)

É, na verdade, com esta avaliação do valor da moda em geral e de modas particulares na vida social que está preocupado oA..Este posicionamento tem sua importância mas é prejudicađo neste caso por certas deficiências teóricas que pouco fazem avançar a compreensão do fenômeno. $\mathrm{O}$ A. mesmo avisa que não pretendeu inovar nada nesta área e que não se tratava desde o início de fornecer uma reflexão elaborada mas "apenas algumas observações episódicas e ocasionais que me foi possível anotar aqui e ali, tiradas, nestes últimos tempos, de jornais e revistas". Em geral considera os diversos problemas que se podem formular a propósito das modas que vai examinando mas sempre opta, em suas explicações, por uma observação empírica que forneceria alguns dados objetivos e irrefutáveis para além das possiveis interpretações. É notório, no entanto, que a dicotomia entre razões utilitárias e valores ideais não pode dar conta dos problemas relativos a objetos materiais, aos produtos industrializados em particular, como sistemas de significação.

É possível encontrarmos no texto alguns conselhos como aquele dirigido aos homens, instando-os a preocuparem-se com o fato de "estar na moda", não em busca de frivolidades estéticas como seria o caso para as mulheres, mas para um desempenho mais eficaz em seus papéis sociais. Obviamente, é todo o problema das funções da moda em vestuário nas distinções de gênero que, num trabalho crítico, interessaria muito mais colocarmo-nos à distância para analisá-lo do que simplesmente reafirmar o desempenho de certos papéis. É um problema que preocupa oA. e reaparece em seus comentários sobre a moda da magreza, do travestismo, etc., ou sobre a questão do disfarce, formulada a propósito da moda nos vestuários para festas noturnas ou para fãs de música rock.

Não há demérito algum na tentativa de elaborar julgamentos sobre modas particulares e moda em geral mas neste caso, como os exemplos indicam, a perspectiva crítica enfraqueceu-se.

DURAND, José Carlos. Moda, luxo e economia. São Paulo: Editora Babel Cultural, 1988, 135p. (FSM, FE/USP, MAC/USP, MP/USP)

A pesquisa realizada peloA. enfoca os dois pólos da produção de roupas de moda que organizam a indústria do vestuário e que surgiram em meados do século XIX, a alta costura e a confecção industrial. Mas concebe ainda um capítulo para a moda no Brasil e outro para os mais recentes desenvolvimentos da moda no mundo e o problema do estatuto artístico da moda. Sua abordagem da história da moda nas sociedades industriais é um subsídio para a tentativa de elaborar uma sociologia da moda, explicando-a em termos de estratificação social e constituição de mercados.

Há uma diversidade de assuntos e problemas abordados no campo da moda - o vestuário como sistema de comunicação e meio para construção de identidade, a hegemonia do vestuátio ocidental no mundo contemporâneo, etc. - e a todos eles $\mathrm{o}$ A. aplica seu enfoque. A constituição da alta costura com a fundação da Maison Worth deve ser entendida como o surgimento e o desenvolvimento de um setor de bens e serviços de luxo na Paris da segunda metade do século XIX, possibilitado pela existência de uma elite com disposição psicológica para o consumo e o lazer dado o final da guerra franco-prussiana (é o início da Belle Époque) e 
pelo florescimento do comércio com as novas facilidades para circulação de mercadorias (avenidas e estradas de ferro) e de propaganda (as revistas ilustradas de moda).

Uma das passagens mais interessantes do livro é aquela sobre o comportamento singular desenvolvido por alguns costureiros brasileiros, sendo os exemplos mais destacados, Dener e Clodovil. Neste caso, a sociologia da moda pode entendê-lo como estratégia promocional à falta de um "capital de cultura" que garantisse notoriedade e acesso aos círculos sociais de elite. O costureiro como um homem com comportamento feminino é já uma imagem associada a esta atividade. No entanto, costureiros de outros países não precisaram exacerbá-lo para garantir algum status, uma vez que eram oriundos das elites econômicas e culturais de seus paises. Dener e Clodovil sempre enfatizaram na mídia sua origem simples e "atacar de louca" consistia, na verdade, num "caminho rentável" para a notoriedade, o que significava mais exatamente sucesso de mídia.A associação entre "frescura" e carisma deve ser entendida, então, como um investimento na própria imagem para obtenção de prestígio social e aceitação no restrito mercado de roupas de luxo no Brasil.

ECO, Umberto et al. Psicologia do vestir. Tradução por José Colaço. 3.ed. Lisboa:Assírio e Alvim, 1989,87 p. (FSM, MP/USP)

Trata-se de uma coletânea de cinco textos e, apesar do título, apenas um único artigo procura analisar as motivações psicológicas implicadas na utilização do vestuário. Todos estão voltados para o público não especializado pois procuram discutir as transformações sociais e políticas promovidas pelo surgimento e intensa difusão da "cultura jovem" (observe-se que sua primeira edição é de 1975).

O texto de Umberto Eco, "O hábito faz o monge", abre o livro e propõe justamente a superação de algumas idéias do senso comum sobre o vestuário como mèio de comunicação, a partir da análise semiológica. A abordagem é mais geral e procura indicar que as formas não-verbais de comunicação constituem-se como códigos, e, portanto, formam sistemas de regras e equivalências que devem ser descobertas e analisadas.

Este objetivo exige, em primeiro lugar, a crítica da idéia geralmente aceita de que aquelas formas acima referidas seriam expressão de fenômenos naturais e apenas à linguagem verbal, considerada o único processo regulado por convenções exclusivamente para produzir significados, se reduziria o fenônemo cultural da comunicação. Seria preciso, segundo o A., demonstrar a convencionalidade de posturas corporais, gestos, variações da fisionomia, inflexões de voz, que explicariam, por exemplo, as variações de valor semântico destes elementos segundo zonas étnicas.

É preciso também criticar a distinção entre atos de comunicação que são concebidos exclusivamente para produzir sentido e tudo aquilo que é criado para desempenhar uma função prática, considerando que a língua pode ser utilizada não para comunicar mas para estabelecer relações de sociabilidade (cumprimentar uma pessoa, por exemplo) e que, ao contrário, objetos podem servir para a produção de sentido como seria o caso de um casaco de peles (um status symbol). Este último exemplo é importante no texto para as questões sobre o vestuário pois definiria a moda como um dos fenônemos nos quais num objeto material o valor comunicativo supera em muito sua funcionalidade prática. Por fim, é preciso considerar a distinção entre códigos fortes que se modificam lentamente pois suas convenções são mais sólidas e códigos fracos, que se modificam freqüentemente, o que seria o caso para o vestuário. A diferença está na velocidade de transformação destes códigos e não na eficácia comunicativa de cada qual, pois se considerarmos as sanções para os desvios, em ambos têm o mesmo efeito: alguém que cometa graves erros lingüísticos ou compareça ao local de trabalho com um traje completamente inadequado pode ter recusado um pedido de emprego. A conseqüência desta distinção é que o pesquisador que se interessar pelo vestuário terá que enfrentar problemas como, por exemplo, a veiculação de um mesmo significado por diferentes significantes (na Europa, inicialmente o dândi usava calças com bainha; décadas depois desta escolha, um dândi identificava-se por sua calça sem bainha).

Eco recheia seu texto com inúmeros exemplos claros e precisos que vêm substituir uma discussão mais conceitual e no final exorta seus leitores a não abandonarem aos especialistas o tema do vestuário como comunicação. No texto de Renato Sigurtá, "Delineamentos psicológicos da moda masculina", encontramos como objeto de reflexão as motivações psicológicas profundas que impeliriam o homem a usar vestuário, as quais não estariam referidas nem a necessidades de proteção (muito mais simbólicas do que pragmáticas), nem a preocupações com pudor, desacreditadas desde sempre. Seriam duas - sexual e de segurança - e estariam ligadas à atividade de decoração do corpo. Seria nesta função estética que o vestuário encontraria sua própria razão de ser. Na primeira tratar-se-ia de manifestar o sexo das pessoas, explicitamente para as mulheres e simbolicamente para os homens, sendo esta a chave para compreensão do significado de peças como o leque ("que se abre convidativo"), a gravata, a bengala e o uso de espada como emblema. Na segunda tratar-se-ia do problema da identidade, que diminuiria a ansiedade das pessoas, fornecendo-lhes a localização imediata de cada qual na trama das relações sociais. 
É este esquema que nos permitiria compreender os significados do vestuário moderno, sobretudo as transformações do vestuário masculino.A Revolução Francesa e o industrialismo retiraram dos trajes masculinos os elementos antes abundantes, que denotavam todo o tipo de diferenciação: da peruca empoada e da casaca ornamentada, passou-se, em curto espaço de tempo, ao terno cinza. Esta profunda modificação diz respeito ao problema da segurança, mas com relação ao fantasma da castração: a imagem de superioridade dos homens estaria ameaçada diante das conquistas femininas.A diferenciação extrema entre homens e mulheres foi uma primeira resposta masculina que explicaria a enorme distância estabelecida entre o padrão de vestuário próprio de cada qual. O fracasso desta resposta torna-se patente na modificação do padrão do vestuário masculino, que busca retomar a ornamentação, agora considerada característica feminina, tentando por fim ao fantasma.

Já no artigo "Moda, consumo e mundo jovem", Marino Livolsi está preocupado em analisar o alcance das transformações políticas e sociais promovidas pela juventude, abordando as mudanças nos estilos de vida no que se refere à atividade de consumo. O vestuário é aí reportado como índice fundamental pois seria uma das principais formas de promover a identidade de um grupo, diferenciando-o dos demais, fato que tem para o A. uma conotação positiva, uma vez que a possibilidade de um grupo social expressar sua identidade está no próprio funcionamento das sociedades modernas e industriais que permitem, ao lado de uma estratificação vertical, a existência de uma estratificação horizontal entre os diferentes grupos sociais de um mesmo nível social.

A análise do consumo, no entanto, pode indicar uma outra dimensão das transformações ocorridas. A moda jovem valoriza a expressão individual e a inovação, valores da modernidade, mas a aquisição de itens importantes como o vestuário é, na verdade, restrita a determinados níveis de rendimento. O novo estilo de vida, portanto, pode significar mais uma das formas de estratificação vertical nas sociedades de consumo.

Francesco Alberoni em, "Observações sociológicas sobre o vestuário masculino", também busca nas transformações da roupa masculina a chave para compreensão das mudanças sociais na atualidade, neste caso como índice das modificações na estrutura de classes. O traje burguês (camisa, gravata, casaco, calças e mais um sobretudo, impermeável ou capote) demonstraria claramente estas relações. Surgindo no início do século XIX e afirmando-se após a Revolução (burguesa) de 1848 correspondeu à hegemonia de uma classe social específica e constituiu uma de suas marcas distintivas.

No início do segundo pós-guerra o terno de cores escuras atingiu seu apogeu, tornando-se a mais difundida roupa masculina mas, ao mesmo tempo, começou seu declínio pois, com o surgimento da burocracia técnico-industrial, instituiu-se uma divisão entre roupa de trabalho e roupa de lazer para atividades do tempo livre, banindo desta última categoria o traje burguês. A cultura juvenil, resultado do prolongamento do período de exclusão dos jovens do trabalho ativo (contingente expressivo deles passou a freqüentar a universidade), tornou seu tempo livre um espaço para a criatividade e o surgimento de valores hedonistas. O novo vestuário juvenil surge nesta oposição trabalho/lazer, contrapondo à uniformidade da roupa de trabalho a liberdade de invenção da roupa jovem (que tenderia a um desregramento prejudicial à vida em sociedade, observa o $A$.). Gillo Dorfles escreve sobre os "Fatores estéticos no vestuário masculino" A roupa seria necessária e indispensável às pessoas, seja para cobrir um corpo "feio", seja porque seria um meio de comunicação, fato este que teria estimulado pesquisas, como a de Barthes, sobre o código que organiza a linguagem do vestuário. OA. faz estas constatações para tornar-nos mais críticos da moda do nude look e incentivar a reflexão sobre o vestuário, particularmente o masculino, como fator estético da nossa civilização. Esta proposta, ele observa, constituiria um problema nas sociedades modernas industrializadas mas, ao mesmo tempo, haveria a possibilidade de pensarmos a educação estética da população através dos produtos para consumo de massa, nos quais bons resultados podem ser atingidos quando ocorre um equilíbrio entre tradição e novidade. O vestuário é estratégico para a análise pois, de modo geral, permite larga gama de inovaçôes por parte do usuário e, particularmente para a Itália, seria na atualidade o setor de manifestações estéticas mais aprimoradas e que como historicamente se verifica, pode manter intercâmbios com o campo artístico (como a influência da oprart demonstraria); o vestuário masculino, especificamente, ao recusar o padrão fixado pelo terno cinza burguês, abre-se para a expressão criativa realizando, nos termos do A., a poética do objeto industrial e da arquitetura formulada pela Bauhaus.

Por fim, Giorgio Lomazzi retomando em "Um consumo ideológico" o tema da moda em vestuário nas sociedades de massa põe em evidência suas relações com a publicidade, duas atividades que estariam em contradição pois se a primeira pretende a identificação com um grupo social específico, através de uma manifestação estética buscando a diferenciação, a segunda é um fenônemo utilitário e busca a uniformização do modo de vida em toda a sociedade. No entanto, a industrialiazação da moda juntou a ambas e oA.discute as dificuldades colocadas nesta situação à escolha individual. 
FREYRE, Gilberto. Modos de bomem e modas de mulber. Rio de Janeiro: Record, 1987, 181p. (ESALQ/USP, FIL/USP, IEB/USP, MP/USP)

Uma preocupação normativa orienta todo o texto doA.:valorizar os elementos e caracteres que, respectivamente, na cultura e na raça favoreçam a miscigenação num povo, eixo do surgimento no Brasil do que ele denominou uma metarraça.A miscigenação não significa nesta formulação mistura aleatória mas síntese: conjugação de elementos que produz novos e diferentes elementos irredutíveis aos primeiros. Portanto, oA. pretende colocar-nos diante de um processo que, em primeiro lugar, busca um resultado específico, o que exige um ponto de equilíbrio aquém do qual nada de novo pode surgir e além do qual produz-se um excesso; e em segundo lugar, cuja maneira ideal de realizar-se é a adaptação: uma conciliação entre o já dado e uma novidade.

É a partir deste esquema geral que analisa a moda, considerando-a sempre em três planos. O primeiro é aquele dos condicionamentos gerais das inovações, que podem ser entendidos sob a noção de tradição, necessários para a estabilidade; o segundo é o da atuação individual inovadora, que deve promover a adaptabilidade; $o$ terceiro, que ao contrário dos outros dois deve ser evitado, é o do excesso da criação arbitrária, que foge completamente à tradição.

Assim, quando se preocupa em discutir a moda como fenômeno sociológico, fixando alguns princípios de sua análise, argumenta que ela não deve ser compreendida como criação arbitrária e individual mas sim na consideração dos seus condicionamentos sociais: transformações nas técnicas e nas relações entre sexos, gerações e condições sócio-econômicas.Ao mesmo tempo, devemos ter em conta a subjetividade presente na moda - existem "modas de pensar, sentir, de crer, de imaginar" -, que permite a escolha individual e não a simples imposição do costume. Isto significa que não podemos desprezar as atitudes no sucesso ou fracasso de uma moda, um erro que poderíamos notar, por exemplo, em Sapir, no seu clássico estudo (mas Sapir não desconsideraria de todo a atuação individual, observando-a apenas naquele terceiro plano dos excessos, registrando os exageros de mulheres menos jovens na adoção de modas de embelezamento feminino).

OA. discute a partir deste ponto o que seria apolíneo ou dionisíaco em moda e o mesmo esquema de análise é posto em jogo, agora em termos de "compensações" que impedem o triunfo de modas radicais sobre as tradições. A um período de certo predomínio do apolineo, a época vitoriana por exemplo, sucederia um período de inovações dionisíacas (como aquele que viu surgir a jupe-cullote), acrescentando o autor que este movimento cíclico poderia ser verificado em outros periodos históricos. Com relação ao tema de uma nova concepção de feminilidade, marcada pela redução das diferenças entre masculino e feminino, devemos, segundo o A., evitar dois tipos de desequilíbrio que estariam ocorrendo: a masculinização da mulher e os excessos nas inovações que têm apelo sexual.

O papel do designer pode ser inteiramente entendido a partir desta perspectiva. Por um lado, está subjugado por aspectos econômicos da moda feminina pois deve conceber modelos em indumentária que atendam às novas possibilidades das mulheres de classes de baixa renda de imitar as mulheres de classes economicamente dominantes e as necessidades de consumo conspícuo destas últimas para demarcar o status dos maridos (quando se trata de famílias burguesas). $O$ designer embora um criador não pode ser arbitrário pois deve atender a estas demandas. Por outro, não é elemento passivo, uma vez que se há condicionamento em torno dos materiais que servem à confecção, é necessário que seu trabalho espelhe aos olhos da cliente a última moda, o dernier cri na expressão recuperada pelo A. e aí sua sensibilidade deve ser utilizada para responder adequadamente a esta demanda psicológica da clientela.

As adaptações de modas européias e norte-americanas ao trópico, promovidas por mulheres brasileiras, assumem importância fundamental no seu trabalho. O mesmo esquema de análise é acionado a partir de considerações sobre o feminino: a tendência das mulheres a seguirem uniformemente a moda é contrabalanceada pela "argúcia feminina" em reagir à homogeneização e ressaltar traços pessoais. É este equilibrio que justifica para o autor sua defesa das adaptações que mulheres brasileiras fazem de modas estrangeiras.

O mesmo enfoque é válido para o exame das diferentes influências sobre a moda brasileira. Uma primeira é a da moda estrangeira como, por exemplo, nos trajes de banho de mar: se, de forma geral, viriam passando de um extremo moralismo a uma extrema licença, no Brasil teriam favorecido a valorização da morenidade característica da pigmentação tropical, tornando moda o bronzeamento de pele. Outra é a que surge no âmbito da cultura popular. Segundo o A., os tipos não-senhoris de mulher colocaram em voga o uso de rendas de tipo popular, sandálias, tamancos e uma diversidade de ornamentos, alguns de origem africana ou indígena. Além disso, no período patriarcal havia influências recíprocas nos adornos de sinhás e mucamas. Estas fontes populares também colocam o problema dos extremismos na adaptação e não devem ser consideradas acriticamente como lugar da pura autenticidade: exemplo de excesso neste assunto seria o uso de palavrões pelas mulheres na atualidade, moda de origem popular que $o$ A. censura firmemente.

Em resumo, quanto às influências sobre a moda feminina brasileira, o A. considera três fontes de produção: a 
importação de artigos estrangeiros; a fabricação brasileira de produtos que não atendem a especificidades regionais; e a confeç̧ão de artigos ecologicamente adaptados. Relativamente a estas três influências, que são concomitantes, não devemos defender o privilégio de nenhuma, à mulher cabe a opção pessoal pelos artigos de seu interesse. Agindo assim, não se trata para oA. de deixarmos margem à escolha arbitrária que introduziria um desequilíbrio entre aquelas fontes pois o A. acredita que as mulheres estão se voltando para produtos ecologicamente adaptados, que ao mesmo tempo obedecem a padrões de qualidade artística (ou seja, que o processo de adaptação é eficaz, também neste caso, e promove um equilibrio entre as diferentes fontes de influência).

Este é em linhas gerais o esquema de análise que nos é apresentado e também aplicado a outros temas discutidos no livro, como a importância das ancas de mulher enquanto aspecto dignificante da condição senhorial. No entanto, é preciso ressaltarmos que a questão da adaptabilidade pode, ainda, ser pensada nã̃o em relação a um só país, no caso o Brasil, mas nas suas relações exteriores pois trata-se de propor o tema do equilíbrio aplicado às relações internacionais.A questão da adaptação de modas no Brasil modifica-se, assim, em certos momentos para o problema do país como exportador de modelos em modas e costumes. $O$ autor chega mesmo a defender a necessidade de enfatizarmos nas instituições responsáveis por nossas relações exteriores uma política cultural que não se descuide das produções de moda.

GLOSSÁRIO têxtil e de confecção: inglês-português. Rio de Janeiro: SENAI/CETIQT: CNI/DAMPI, 1986, 310p. (MP/USP)

Publicação voltada para os profissionais da área de têxteis e confecção, traz os termos técnicos referentes a estes setores industriais. Produto da fusão de outros dois glossários têxteis publicados anteriormente, constitui esforço das instituições envolvidas em sua elaboração para fornecer instrumentos de apoio a pesquisa de novas tecnologias.

GONTIJO, Silvana. 80 anos de moda no Brasil. Rio de Janeiro: Nova Frontreira, 1987, 130p., il. (ECA/USP, IEB/USP, MP/USP)

Publicação comemorativa dos 80 anos de fundação da Cia.Têxtil Ferreira Guimarães.Trabalho de apresentação esmerada: impressão em papel couché, capa dura forrada com tecido, acondicionado em caixa de papelão estampada.

Obra de divulgação elaborada com o propósito de constituir o primeiro trabalho de referência sobre a evolução da moda no Brasil, é dirigida a profissionais de moda, estudiosos, estudantes, diretores de arte, produtores de teatro, TV e cinema, publicitários. Reúne informações de diversas fontes (conforme relação apresentada): documentos e publicações, entrevistas, álbuns e arquivos fotográficos, pinturas e desenhos. Contém 300 ilustrações entre caricaturas, fotos e, sobretudo, anúncios comerciais.

O livro é dividido em nove partes, cada uma dedicada a uma década do século XX. No final de cada parte apresenta-se um quadro com os tipos de vestuário feminino - para o dia, noite, praia, primavera/verão, outono/ inverno, toilette, esporte, roupa branca, etc. - predominante em cada periodo. Traz ainda uma lista alfabética de "grandes nomes", com dados biográficos de modistas e costureiros e informações sobre lojas de moda, um pequeno glossário e um encarte com reprodução das cores mais utilizadas em cada década. As ilustrações dominam o livro, apresentando-se o texto no lado esquerdo ou direito da página, numa coluna em destaque, sintetizando as informações mais divulgadas sobre cada período e transcrevendo trechos de cronistas ou publicações contemporâneas.

Procura-se situar a moda nos cenários nos quais surgia e tratar os fatores estéticos, sociais, econômicos e políticos que mais a influenciavam. Estranhamente, no entanto, estabelece a periodização por décadas e não em consonância com os valores aludidos, organização que se, por um lado, procura sistematizar as informações, por outro, está longe de qualquer consideração baseada na historiografia atual.

HAEDRICH, Marcel. Coco Chanel. Rio de Janeiro: Rocco, 1988, 237p., il. (FAM)

O A., editor de moda, conviveu com Coco Chanel entre 1959 e 1971, ano da morte da famosa estilista e elaborou sua biografia gravando diversos depoimentos neste periodo de 12 anos. $O$ sucesso de Coco Chanel e as suas dificuldades de relacionamento com amigos e a mídia dominam os relatos.

HISTÓRIA DA CAMISETA. S.l. Hering, 1988, 162p., il. (ECA/USP, MP/USP)

Esta publicação foi realizada sob patrocínio da Companhia Hering e constitui obra de acabamento esmerado e ricamente ilustrada. É uma coletânea de vários textos de diferentes tipos, enfocando o tema sob diversas 
perspectivas e em diferentes campos. Sobre a camiseta temos artigos, ensaios fotográficos e encerrando o livro um texto de ficção; há abordagens historiográficas, sociológicas, econômicas e de crítica artística, examinando esta peça de roupa e suas significações nas histórias em quadrinhos, no cinema, nas artes plásticas, na música, na moda propriamente dita e no marketing, segundo a opinião de especialistas em cada área.

O livro é também produto dos esforços de Ruth Joffily, destacada profissional do jornalismo de moda e autora da introdução, que busca, sempre numa reflexão mais ampla, compreender a moda em suas dimensões sociais e culturais, neste caso reunindo diversos autores. Podemos, então, acompanhar a camiseta desde a sua origem como underweare mas já logo representada nos começos dos meios de comunicação de massa (e mesmo antes, na pintura impressionista) até sua transformação em símbolo de contestação de vanguardas artísticas e políticas no pós-guerra e em produto de consumo de massa a partir dos anos 60 .

JOFFILY, Ruth. Marília Valls: um trabalho sobre moda. Rio de Janeiro: Salamandra, 1989, 141p., il. (SENAC)

Este livro é uma biografia da estilista e empresária Marília Valls, composta pela jornalista e editora de moda Ruth Joffily.A perspectiva do trabalho é muito rica pois procura manter o tempo todo o entrelaçamento de uma experiência pessoal e transformações sociais e culturais, mais especificamente a trajetória de uma profissional de moda e o desenvolvimento da indústria de moda prêt-à-porter no Brasil. Na organização do texto aparecem em primeiro plano os dramas pessoais de Marília Valls, as mudanças de vida pelas quais passou, sua energia para enfrentá-las, tudo isso relatado em depoimentos seus e de amigos e profissionais que com ela trabalharam. Ao redor destes relatos, a A. tece comentários para formar um "pano de fundo" histórico e social dos acontecimentos da vida pessoal de sua biografada.

A vida da estilista é descrita como uma trajetória de sucesso pessoal e profissional: de uma mulher educada para uma relação de submissão ao marido à estilista-empresária realizadora. Nesta transformação está implicada uma mudança de valores: à mulher educada num ambiente conservador (mas já incomodada com as restrições) substituiu-se, ainda que não inteiramente, a mulher empreendedora e criativa. É a situação que se configura em toda sua intensidade quando Marília Valls recorda sua entrada em 1962 na Malharia Arp, seu primeiro trabalho profissional como estilista, ou ainda no começo dos anos 70 , quando da sua saída da empresa Nova América com o objetivo de montar um butique própria. Conforme nos relata, deixava para trás valores familiares - a dedicação ao marido, a responsabilidade pela educação dos filhos, a convivência com famílias de renome - para na vida profissional que então iniciava adotar outros valores - independência em relação ao marido e eficiência na condução de negócios empresariais, sobretudo pelo que esta atividade exige đe ousadia e arrojo pessoais.

$\mathrm{Na}$ sua biografia poderíamos acompanhar então a realização pessoal de uma mulher através do ingresso no mercado de trabalho. Este é talvez o tema mais importante abordado no livro, principalmente porque a formação do mercado de moda prêt-à-porter no Brasil é em grande parte descrito em função de transformações nas representações sobre a mulher. Nos anos 50/60 as novas qualidades que caracterizariam a mulher seriam a praticidade, a espontaneidade e a juventude e para atender a esta nova imagem amplia-se a oferta de publicações especializadas em moda feminina - Manequim (1959), Claúdia (1961), Desfile (1969), Nova (1973) - agora voltadas para facilitar tarefas domésticas e sustentar a imagem de uma mulher independente; ou surgem os fios sintéticos para confecção, também liberando-a do mesmo tipo de tarefas ao tornarem dipensável passar a roupa. Estas mudanças estariam, por fim, inseridas num conjunto mais amplo de transformações, definido pela A. como um processo de democratização da moda, "o direito de cobrir o corpo com uma idéia, com uma fantasia, de colocar para fora um pouco da individualidade de cada um", o que significa caracterizar as noudanças através das novas possibilidades de representação de si mesmo.

A A. compreende, portanto, a constituição do mercado como decorrência da expansão da demanda. As transformações na oferta não deixam de aparecer no texto como, por exemplo, um fator conjuntural para o desenvolvimento do prêt-à-porter no Brasil - em meio à elevação do poder aquisitivo da classe média, ao processo de democratização da moda, ao espírito do novo (incentivado pela moda bippie), teríamos também uma reação da indústria têxtil à moda mini, que então diminuía em muito a demanda por tecidos. No entanto, uma abordagem mais decidida do mercado de vestuário de moda no Brasil pelo lado da oferta abriria novas perspectivas sobre o tema e enriqueceria a própria biografia de uma estilista como Marilia Valls.

Podemos entender a contratação de Marilia Valls pela Malharia Arp, por exemplo, como uma tentativa bem sucedida da empresa em aumentar os cuidados quanto à estética de suas mercadorias.A estilista introduziu o "o gosto" na produção industrial. De uma maneira mais geral podemos afirmar que o estilismo industrial foi buscar num know-bow já estabelecido o aprimoramento da qualidade de seus produtos. Seria preciso considerarmos, então, as necessidades da indústria da moda que impulsionaram transformações nas linhas de 
produção, integrando um "bom-gosto" consagrado anteriormente e tão utilizado para fins de distinção social (este era um investimento familiar que Marilia Valls manteve, era o seu lado pink, mesmo em meio a dificuldades financeiras, preocupando-se sempre com os sinais de refinamento e riqueza afim de manter relações que representassem possibilidade de ascensão social).

Esta abordagem daria relevância aos próprios trabalhos de Marília Valls, um aspecto pouco explorado nesta biografia centrada principalmente em acontecimentos de sua vida pessoal e profissional (ao final há um apêndice descritivo das principais coleções da butique Blu-Blu, compreendendo o período 1972/1987). Em que medida a análise detalhada dos modelos e coleções concebidos por ela nos permitiria entender o encontro entre "bom-gosto" para fins de distinção social e produção em série de tecidos e vestuário? O que nos esclareceria sobre o processo de "democratização da moda" afirmado para a expansão do mercado nas décadas de 60 e 70 ?

\section{JOFFILY, Ruth. Jornalismo e produção de moda. Rio de Janeiro: Nova Fronteira, 1991, 148p. (SENAC)}

Este livro é resultado do curso de extensão universitária Jornalismo e produção de moda e das atividades do Núcleo de Moda, implantados em 1987 na Faculdade Cândido Mendes pela A. e outras personalidades da área. Trabalho voltado para a formação de profissionais nesta especialidade do jornalismo afirma como seu objetivo principal o compromisso com o público leitor. Por um lado, como prestação de serviço, deve manter este público atualizado quanto a lançamentos e tendências, sendo de fundamental importância fornecer-lhe informação objetiva - o próprio livro traz alguns instrumentos de trabalho para este fim, como um pequeno glossário - e critérios que permitam.uma escolha, critérios estéticos sem dúvida mas também pragmáticos, que possibilitem às pessoas adequarem os tipos de roupas que desejam a suas limitações financeiras. Por outro, como atividade referida a uma prática fundamental na vida pessoal - o vestir-se na moda - sua principal finalidade seria o desenvolvimento de uma crítica de moda que permitisse aos individuos uma escolha livre, feita segundo critérios pessoais, do seu próprio vestuário. A crítica de moda é necessária, então, ao jornalista especializado para que não fique atrelado aos interesses comerciais e publicitários das empresas do setor e seria condição para a valorização profissional da atividade. Este é o principal problema que perpassa todo o livro.

A crítica de moda estabelece seus compromissos com o consumidor final de vestuário para que ele realize com segurança suas opções. Em toda a sua extensão esta crítica pretende um discernimento voltado para uma decisão de consumo. Esta concepção da atividade crítica parece, no entanto, conduzir a uma abordagem restrita do fenômeno moda ao identificá-lo com a expansão do mercado consumidor.

Conforme nos expõe a A., a função da crítica de moda, como de toda forma de comunicação, seria tornar inteligíveis às pessoas a organização social na qual vivem e para atingir este fim é preciso que tenhamos consciência da confecção e consumo do vestuário como atividades sociais. Recolhe em vários exemplos esta dimensão social das roupas: a historicidade dos trajes masculino e feminino que variam conforme os papéis atribuídos a homens e mulheres; as transformações no significado da nudez; o uso do vestuário para finns políticos como no caso da unificação promovida, na Idade Média, por Carlos Magno; ou ainda o problema da influência estrangeira no vestuário brasileiro, problema cultural pois que se coloca também em outras áreas como literatura, artes plásticas, música, etc.

Se a importância do vestuário pode ser reconhecida em qualquer periodo histórico e qualquer sociedade, o mesmo não se passaria com a roupa de moda pois ela exigiria o desenvolvimento do mercado capitalista.A breve história da moda moderna - a partir de meados do século XVIII - é composta como uma progressiva "democratização da moda": desde os primeiros estabelecimentos comerciais, passando pela atuação fundamental de Charles Worth e depois de Paul Poiret, Coco Chanel, Dior e outros, até o atual consumo massificado de roupa de moda, é à paulatina afirmação do "estilo" - a liberdade de criação individual - que assistiríamos. Nesta abordagem o corte fundamental está na ampliação do mercado consumidor no século XIX, com a ascensão social da burguesia (período de atuação de Worth), o que tornou dificil à A.reconhecer a existência do fenômeno moda enquanto anteriormente estava restrito à nobreza e não acessível a outras camadas da população. Neste texto a preocupação exclusiva $\mathrm{em}$ afirmar a moda em vestuário como oportunidade de exercício da liberdade individual, portanto, como prática democrática, faz-se em detrimento de outras funções sociais da moda (as variações individuais já ocorriam entre os nobres e para fins de distinção social).

KOHLER, Carl. História do vestuário. Tradução por Jefferson Luís Camargo. São Paulo: Martins Fontes, 1993, 564p., il. (FIL/USP, HIS/USP, MP/USP)

OA. foi um pintor do século XIX que elaborou dois tratados sobre a história do vestuário. Seus trabalhos foram editados e atualizados por Emma Von Sichart, em 1963, numa única publicação.A pesquisadora não se interessou 
por alguns aspectos da obra e suprimiu, por exemplo, os trechos referentes à história dos povos e países estudados. Se a integridade da obra não foi mantida com esta modificação, prejudicando nossa compreensão sobre as concepções đo $A$. sobre o assunto - a própria organizadora do volume remete brevemente na sua introdução os estudos sobre indumentária ao problema do "espírito do tempo" - temos ainda as descrições minuciosas dos trajes com tođo o detalhamento das técnicas de confecção das roupas e são estes aspectos práticos do trabalho que despertaram o interesse em publicá-lo. Preocupando-se em aprimorar nosso conhecimento sobre o vestuário de outros períodos históricos, a pesquisadora produziu fotos com modelos vivos portando as roupas escolhidas e deixa registrados cuidados àqueles que se interessarem em reproduzir os trajes ilustrados dos quais fornece a descrição e todas as medidas para sua confecção. Centrando-se nas atividades de fabricação das roupas, o livro vem de fato auxiliar em área que recebe pouca atenção nos estudos sobre indumentária.

LABIRINTO DA MODA: uma aventura infantil. São Paulo: SESC/São Paulo, 1996, 1v. + encarte, il. (MP/USP)

Labirinto da moda é um conjunto de eventos - exposições, oficinas e espetáculos - idealizados pela curadora Glaucia Amaral, desenvolvidos em torno de um tema - a roupa infantil - e concebidos para interação com crianças. À exposição de objetos e de vasto material iconográfico (realizada entre 16/1/96 e 25/2/96) estavam integrados obras artísticas, filmes cinematográficos, instalações elaboradas especialmente para o evento tais como "Bonecas", de Anna Heylen e "Caracol Peludo", de Renato Imbroisi e, ainda, a montagem de um "Brechó" no qual as crianças poderiam compor sua própria indumentária com as peças lá disponíveis. Ela contou com duas publicações, uma concebida especialmente para manuseio das crianças e outra, o catálogo propriamente dito. Este é totalmente ilustrado e composto por depoimentos, reflexões e comentários de um jornalista, uma psicóloga, educadores e especialistas em artes plásticas e educação; contém, ainda, como encarte, um Guia do Labirinto com um mapa de todos os eventos e explicações detalhadas de cada um deles.

I.AVER,James. A roupa e a moda: uma história concisa.Tradução por Glória Maria de Mello Carvalho.

São Paulo: Companhia das Letras, 1990, 285p., il. (ECA/USP, FAU/USP, FIL/USP, MP/USP)

Renomado especialista na histótia do vestuário, o A. deixa claro que neste livro não pretende desenvolver nenhuma análise sobre as motivações que explicariam a utilização de roupas, procurando antes comentar em especial dois aspectos do vestuário: a forma e o material. De fato, seu trabalho é rico na descrição dos trajes, das técnicas de produção e formas de uso, acompanhada por considerações sobre o vestuário característico de diversos períodos históricos e sobre as circunstâncias históricas - guerras, transformações sociais, etc. - que influenciaram os aspectos enfocados.

Centrando-se no vestuário europeu e mais tarde também no norte-americano, o A. inicia sua história concisa no periodo paleolítico e segue cronologicamente até a atualidade. Apenas em raros momentos ocorreram algumas generalizações, como no último capítulo, aliás escrito por Christina Probert, e o único cujo período abordado recebe uma denominação, "a era do individualismo". Nele se afirma - a propósito da Segunda Guerra Mundial - que as roupas em épocas de guerra mostrariam claramente como a moda refletiria a "atmosfera do momento". É um trabalho extremamente informativo e ilustrado, voltado para um público não-especializado.

LIPOVETSKY, Gilles. Império do efêmero: a moda e seu destino nas sociedades modernas. Tradução por Maria Lúcia Machado. São Paulo: Companhia das Letras, 1989, 294p. (FSM, ECA/USP, FE/USP, FIL/USP, MP/USP)

Vide acima, páginas 260-269

MANDEL, Rachel. Arquivo ilustrado de trajes bistóricos: do antigo Egito ao século 19. Rio de Janeiro: Ediouro, 1985, 92p., il. (FSM, FIL/USP, MP/USP)

Nesta obra temos um conjunto de desenhos acompanhados de legendas que indicam a época dos trajes, ilustrando, assim, o vestuário característico de cada sociedade.

MARQUES, A. H. de Oliveira. Figurinos maçônicos oitocentistas: um "guia" de 1841-42. Lisboa: Editorial Estampa, 1983, 79p., il. (MP/USP)

OA. reuniu publicações esparsas de uma das Obediências da Maçonaria portuguesa do século XIX, o Oriente 
Escocês de Silva Carvalho (fundado em 1841), as quais resultaram da preocupação dos seus dirigentes em divulgar entre os adeptos todo o ritual das sessões dos vários graus (de 1 a 33) e as insígnias específicas de cada um. Neste sentido a publicação atual cobre sistematicamente toda a indumentária utilizada.

\section{A MODA NA REPÚBLICA. Museu da República. Rio de Janeiro: Erregê, 1990, 23p. (MRep)}

Publicação que acompanhou a mostra $A$ moda na República, evento comemorativo da reabertura do Museu da República ao público, em 1990. Dois aspectos do fenônemo são abordados, sua dimensão histórica e sua constituição como produto do trabalho.Apresenta-se, resumidamente, a evolução da moda desde a Belle Époque até a atualidade, com um segmento especial para o Brasil desde o século XVI, registrando-se as principais mudanças no vestuário de moda que caracterizam diferentes períodos e os fatos sociais, culturais, políticos e psicológicos que as impulsionaram.

O texto se encerra com uma breve discussão sobre os fundamentos econômicos da moda - com destaque para a influência dos interesses econômicos da indústria e a hegemonia cultural dos países desenvolvidos - retomando-se, ainda, o problema de aspectos políticos e sociais que determinam a moda e enfatizando-se as questões de ascensão social e predomínio de um "espírito do tempo".

O'HARA, Georgina. Enciclopédia da moda: de 1840 à década de 80. São Paulo: Companhia das Letras, 1992, 300p., il. (FIL/USP, MP/USP)

A perspectiva sobre moda em indumentária que a toma como linguagem e reflexo da sociedade - concepções problemáticas seja porque não possíbilitam pensarmos a sociedade em termos de sistema, seja porque pesquisas recentes têm apontado o fato de que a produção de sentido através da indumentária não se realiza segundo um modelo lingüístico de comunicação - tem impulsionado e justificado a elaboração de obras abrangentes que reunem e organizam a massa de informações sobre o assunto. É o caso desta enciclopédia que inclui não só os nomes de grandes estilistas mas de outros profissionais da área - ilustradores, fotógrafos, editores de moda, figurinistas de cinema - de personalidades influentes em moda como, Jackie Kennedy Onassis, Brigitte Bardot, Eisenhower e outros, além é claro, dos termos que designam as roupas, acessórios e tecidos, sendo bastante atualizada em todos estes pontos.

Sinalizando esta abrangência, a A. discorre rapidamente em prefácio sobre o desenvolvimento da moda na Europa e nos Estados Unidos desde o século XIX, com exemplos significativos de todos os aspectos citados acima. No final do texto faz uma avaliação do atual recuo da alta costura e da hegemonia do prêt-à-porter na produção de moda, que se afasta das idéias mais aceitas. Salienta a acessibilidade às roupas de moda mas ao invés de concluir pela ampliação da liberdade de escolha afirma que ocorreu uma padronização dos modelos que, na verdade, diminuiu o leque de opções. Um posicionamento mais crítico, que foge ao consenso que vai se formando a respeito da democratização da moda, a partir do segundo pós-guerra.

PASTOUREAU, Michel. O tecido do diabo: uma história das riscas e dos tecidos listrados.'Tradução por Isabel Teresa Santos. Lisboa: Editorial Estampa, 1992, 116p., il. (MP/USP)

OA. propõe neste livro uma instigante análise sobre um elemento do mundo físico (com significativos efeitos no campo visual), constantemente apropriado ou modelado pelo homem para a produção de sentido: as listras. Os traços que dispostos sobre um plano o constituem como uma superfície riscada (ou listrada) são uma marca cultural pois servem para assinalar, classificar, hierarquizar e controlar elementos do meio físico nos quais existem (animais, por exemplo) e objetos nos quais são aplicados (basta pensarmos em casos atuais como envelopes para cartas especiais, bilhetes de entradas e todo tipo de etiqueta). Com esta mesma função são utilizados no mundo social: tecidos e vestuários listrados, escarificações, são exemplos de como as listras são um instrumento de taxinomia social.

Vemos aqui que se trata de uma "problemática da risca", que não é formulada apenas sobre um dos seus possíveis suportes, as roupas. É tema apropriado para o A., um especialista em heráldica, mas o vestuário é reconhecidamente um dos seus suportes mais visíveis e, neste texto em especial, as funções atribuidas aos trajes ou peças de roupas listrados são acompanhadas desde a Idade Média. Neste periodo evidenciavam o estatuto negativo de todos aqueles considerados transgressores da ordem social - judeus, muçulmanos, heréticos, o bobo da corte, o jogral, carrascos, prostitutas, leprosos e personagens imaginários: os cavalheiros desleais dos romances, $\mathrm{Ju}$ Jas do relato bíblico e outros.Analisando fontes iconográficas mas também textuais - legislação religiosa católica, laica (leis suntuárias) e literatura - o A. pode coligir vários testemunhos do caráter discriminatório das listras.

Na Idade Moderna podemos acompanhar uma diversificação das funções das listras acompanhada da 
diversificação de seus significađos. Ao lado das listras difamatórias (o vestuário de presidários é um exemplo claro) temos listras que indicam a condição servil mas não uma exclusão (o vestuário de criadagem que se difundiu extremamente no período) e aquelas valorizantes (utilizadas abundantemente em decoração de interiores e ligadas à imagem do revolucionário), todas agora observadas em termos de sua verticalidade ou horizontalidade.A partir de meadōs do século XIX as listras vão entrando para um novo sistema de significação, desde então percebidas segundo a sua cor e largura, modificação que novamente exige a análise das mudanças nos códigos de moral.A grande penetração que se nota das listras se dá então no vestuário e tecidos que tocam o corpo. Por séculos, as camisas, os véus, a ceroulas, os lençóis só se admitiam na cor branca ou crus, mas a partir daquele período observa-se que a utilização inicial do pastel e do listrado naquelas peças promoveu uma passagem à colorização atual das mesmas, substituindo-se ao branco higiênico o listrado higiênico. As listras não estão mais ligadas somente à negatividade da exclusão mas promovem uma valorização das superfícies às quais são aplicadas, contudo denotando sempre uma exceção - são preferencialmente aplicadas às pessoas de espetáculo, ontem aos palhaços e músicos, hoje aos desportistas:

RANSCHBURG,André. Quem não faz poeira come poeira: histórias de um homem de marketing que faz dinheiro e sucesso fabricando jeans. São Paulo: Best Seller, 1991, 227p. (FEA/USP)

Autobiografia do presidente da Staroup, fabricante de roupas jeans, centrada na sua trajetória no interior da empresa desde a sua contratação em 1978. É um livro de interesse para os problemas referentes à importância da atividade de marketing nas empresas de confecção. O A. em seu ideário liberal enfatiza a necessidade de "fazer poeira" - antecipar-se aos concorrentes na conquista das melhores oportunidades de negócio - como o objetivo que define o sucesso empresarial. No centro da estratégia que estabelece para atingí-lo está o marketing do produto. $\mathrm{O}$ A. foi, de fato, contratado para desenvolver esta área na empresa e define a si próprio, como vemos no subtítulo, um "homem de marketing", atividade que chega mesmo a marcar sua vida pessoal (Joemir Beting, em seu prefácio, observa este fato e compara o A. a um foguete).

Na direção das atividades de marketing e depois na condução geral da empresa podemos observar como é a preocupação com a "imagem" e divulgação do produto que guia as estratégias de comercialização (o mercbandising nas novelas de televisão) e os planos de expansão da produção (não ampliar a oferta no mercado brasileiro mas exportar para vários países para não "banalizar" a marca enfraquecendo-a, para seus usuários, como estratégia de "distinção"). Fundamental neste aspecto é o capítulo 15 , "Fabricação, Arma dos Negócios", quando: 1) ao falar da organização da produção, vincula a escala de cada unidade industrial e a verticalização da produção (evitando-se a subcontratação de empresas) ao controle de qualidade do produto; 2) justamente neste capítulo volta a afirmar que o "grande negócio da confecção de jeans é conseguir lançar um produto na frente, deixando a concorrência mordendo o pó... consumidor paga por novidades”; 3) ao comentar certas dificuldades de fabricação, ressalta a importância que determinados elementos da roupa, os botões por exemplo, têm para o consumidor e os testes específicos aos quais são submetidos na fábrica. Nos capítulos finais, dedicados à publicidade e ao marketing, podemos acompanhar com maior detalhe o desenvolvimento destas atividades: o difícil relacionamento com as agências de publicidade, a utilização da imagem do presidente da empresa no marketing do produto (inclusive em suas entrevistas a jornais e revistas, algumas transcritas no livro), as modificações nas estratégias de distribuição, etc.

ROSSETTI,Ana. Roupas íntimas: o tecido da sedução. Tradução por Eduardo Brandão. São Paulo: Martins Fontes, 1995, 164p., il. (FAM, MP/USP)

A A. utiliza suas reminiscências pessoais para fornecer dados históricos sobre as roupas íntimas, opinando sobre a sua utilização pelas mulheres como estratégia de sedução.

SAHLINS, Marshall. Notas sobre o sistema do vestuário americano. In: Cultura e razão prática. Tradução por Sérgio Tadeu de Niemayer Lamarão. Rio de Janeiro: Zahar, 1979. p.99-225. (MP/ USP, FIL/USP)

Vide acima, páginas 254-260

SILVA, Gracilda Alves de Azevedo. Bangu 100 anos: a fábrica e o bairro. Rio de Janeiro: Sabiá Produções Artísticas, 1989, 176p., il. (SENAC)

Publicação comemorativa do centenário de fundação da fábrica carioca de têxteis Bangu. É obra de bom acabamento sendo apresentada em capa dura e acondicionada em caixa de papelão, ambas forradas por tecido, 
fartamente ilustrada.A A. já havia se ocupado anteriormente da história da empresa (Bangu: a fábrica e o bairro; um esboço histórico 1889-1930. Rio de Janeiro, 1985).

O texto deixa transparecer pelo menos dois motivos importantes para o desenvolvimento de estudos sobre a fábrica. Primeiramente é uma empresa do final do século XIX, fundada inteiramente com capital nacional e que experimentou rápidos progressos na produção e conquista de mercados. Considere-se também sua influência no desenvolvimento da região onde foi instalada. Ela reorientou as atividades agrícolas das localidades em seu entorno, investindo no setor, produzindo açúcar, fubá, arroz, etc., ou garantindo o fornecimento de matéria-prima, óleo de rícino, polvilho e outros produtos; induziu a urbanização da região formando o atual bairro do mesmo nome e a instalação de infra-estrutura para industrialização, ampliando os ramais de estrada de ferro, construindo uma represa; contribuiu para o desenvolvimento de serviços como escolas, centros de saúde $\mathrm{e}$ hospital.Todos esses possíveis temas para estudos mais detalhados são levantados num relato bastante informativo e claro.

SOUZA, Gilda de Mello e. O espírito das roupas: a moda no século XIX. São Paulo: Companhia das Letras, 1989, 255p., il. (FSM, ECA/USP, FE/USP, FIL/USP, HIS/USP, MP/USP)

Vide acima, páginas 269-262

SPENGLER, Airton. Decifrando a moda: glossário. São Paulo: Editora STS, 1993, 156p. (SENAC) OA. preocupa-se em fornecer ao público um livro de fácil leitura sobre termos da moda, compondo-o em uma linguagem acessível, sem definições rigorosas e polêmicas, buscando apenas "explicar a idéia" à qual cada termo remete. Obra para rápidas consultas, contém ainda uma introdução com breves comentários sobre os termos moda, chic e look e referências a acontecimentos importantes na história da moda no Brasil.

THAMER, Deise Sabbag. $A$ moda dos anos 80. São Paulo: [s.n.], 1987, 143p., il. (SENAC)

Este livro é a reunião dos textos da editora do encarte "Todamoda" dos jornais Shopping News, City News e Jornal da Semana, que circularam na cidade de São Paulo. Através deles a A., sempre procurando dosar opinião e dados sobre as roupas de moda, comenta os principais temas que percorreram a moda da década de 80, tais como a concomitância dos mais diferentes estilos, a importância de um público consumidor ampliado, a profissionalização nas indústrias têxtil e de confecção no Brasil, o entrelaçamento de estilo de vestir e estilo de comportamento, etc.

A análise da abordagem desenvolvida pela A. beneficia-se muito do problema da função do jornalismo de moda ao qual todos os outros estão remetidos. Ela própria preocupou-se com a questão no artigo "Cultura e economia escondem-se nos babados da moda". Percebe-se claramente que é a idéia do vestuário como reflexo dos fenônemos sociais que the permite definir os objetivos $\mathrm{da}$ atividade e as exigências que recaem sobre o profissional. Segundo a A., o jornalista, utilizando-se de sua sensibilidade e experiência, não procura impor uma moda ou uma interpretação unívoca sobre ela mas apenas prever o gosto dos públicos feminino e masculino a cada momento. Sua função é a orientação do consumo mas utilizando-se exclusivamente da informação objetiva que permite às pessoas realizarem suas escolhas particulares.

Nesta perspectiva, por um lado, o jornalismo serve ao consumo, desempenhando uma função crítica que se atém tão somente a perceber o que está ou o que não está na moda no período considerado, sem refletir sobre as mudanças históricas que estruturaram a produção de moda a partir dos anos 50; por outro, ao jornalista na década de 80 caberia sempre manter a noção do prático e usável, mesmo quando comenta os modelos mais fantasiosos, devendo por isso tornar-se atento observador da realidade social. Estas propostas, no entanto, deixam de considerar a mudança fundamental que ocorreu na confecção e consumo de roupas de moda: a existência de um mercado consumidor ampliado para atendimento do qual a produção passa a organizar-se. É esta mudança que define uma das principais características da moda na atualidade: o padrão das roupas não é mais definido pelo luxo da alta costura mas pelo prático e utilizável do prêt-à-porter. O critério estabelecido para o jornalista realizar sua avaliação é ele próprio histórico e uma posição mais crítica exige que se possa refletir sobre ele. Certamente o jornalismo de moda tem a função de orientação mais imediata ao público consumidor mas não deve perder de vista o consumo de massa como fenônemo histórico nas sociedades altamente industrializadas, sobretudo após a Segunda Guerra Mundial.

USTOP: 15 anos. São Paulo: Mauro Ivan Marketing Editorial, 1988, 26p., il. (FSM, ECA/USP)

O livro com capa dura, imita um caderno escolar: apresenta-se com espiral e as páginas foram impressas simulando uma folha pautada. É publicação comemorativa dos 15 anos de produção nacional da roupa jeans 
da marca USTOP (da Divisão Jeans da São Paulo Alpargatas S.A.) que traz material publicitário - cartazes de pontos-de-venda e fotogramas de comerciais televisivos - do produto, disposto em ordem cronológica e acompanhado, a cada página, de rápidos comentários. Ao final, quatro páginas com fotos de profissionais de jornalismo de moda vestindo jeans da marca.

VICENT-RICARD, Françoise. As espirais da moda. Tradução por Maria Inês Rolim. Rio de Janeiro:

Paz e Terra, 1989, 249p., il. (ECA/USP, HIS/USP, MP/USP)

No âmbito dos guias e manuais, este livro tem um certo destaque, pois busca não só difundir informações corretas sobre a moda e sua história mas apresentá-las sob uma análise consistente do seu significado. Esta peculiaridade está relacionada à biografia daA.:consultora de moda, aliou sua experiência profissional à vontade de reflexão sobre o significado da moda e seu alcance como estratégia para expressão pessoal, mas também social e cultural para além do reforço das hierarquias sociais.

AA. faz um relato em tom pessoal. Ela mesma é uma das mais importantes protagonistas das mudanças ocorridas na indústria têxtil e de confecção do pós-guerra, que transformariam os mecanismos de difusão da moda em vestuário, caracterizados agora por sua forte industrialização. Do ponto de vista da fabricação da roupa, estas mudanças designam novas estratégias industriais para ampliação do volume de vendas e conquista de mercados - eis porque a crônica deste processo é em grande parte a competição entre duas potências do ramo: França e Estados Unidos. Estas estratégias consagraram a expansão da roupa ready to wear norte-americana, base para o prêt-à-porter francês.

A industrialização da moda é o novo fenônemo que surge nas sociedades capitalistas após a Segunda Guerra Mundial. Inovação importante deste período é o aparecimento de uma nova atividade nesta área, logo profissionalizada: o estilista de moda. O surgimento do estilista industrial na base da reorganização das indústrias têxtil e de confecção é um fato capital para a pesquisa acadêmica şobre moda e vestuário. A "criação" dos modelos agora organiza-se em bases industriais, ou seja, objetivando o escoamento num mercado que seja ampliado em relação àqueles anteriores à guerra. E o problema dos valores simbólicos investidos nos produtos em série tem aqui um bom campo de análise.

A importância deste manual, por um lado, está em que nos apresenta uma crônica deste processo, montando um quadro informativo sobre os profissionais, as indústrias e toda a rede de empresas envolvidos na produção e distribuição das roupas fabricadas; por outro, apresenta-nos a consciência de um dos agentes envolvidos neste processo, favorecendo uma discussão sobre a origem e o alcance da idéia de "democratização da moda" que marca o atual debate sobre o vestuário nas sociedades pós-industriais. Os argumentos desenvolvidos ao longo do livro constituem um precioso exemplo de elaboração de uma estratégia de mercado que emerge do processo de industrialização da moda.

Os principais pontos desta estratégia aparecem na síntese da atuação da Promostyl - escritório da autora, fundado em 1966 - comentada por Constanza Pascolato na apresentação: 1) operar "verticalmente", intervindo em todos os estágios da cadeia têxtil, da fabricação à distribuição; 2) agir "horizontalmente", estruturando ações entre concorrentes com o mesmo tipo de produto. Uma estratégia harmonizada permite estabelecer normas técnicas para reforçar a mensagem "estilo";3) universalizar tendências de moda, criando gamas de cor, indicar tecidos e sugerir formas. Traçar um conceito global, a partir de temas de moda, que serve de base a coleções para tecelagens e confecções; 4) criar coleções exclusivas, em número limitado, para todas as categorias e estágios da indústria, com a preocupação de uma adequação de imagem, qualidade e personalização.

Trata-se, em primeiro lugar, de articular todas as atividades das indústrias têxtil e de confecção e das empresas de distribuição. Isto significa que devem orientar suas atividades para um funcionamento ótimo da "cadeia" que formam, o que exige produtos, processos e "idéias" comuns ou ao menos compativeis entre si, no interior da cadeia, para que ela possa funcionar como tal. Em segundo lugar, é preciso garantir que a concorrência não se desenvolva anarquicamente, fragmentando inteiramente o mercado consumidor. É preciso também haver um "estilo", padrão predominante que não estenda o leque de opções e garanta a saída dos produtos lançados, os quais, então, estarão de acordo com a "tendência" do período. Por fim, torna-se necessário considerar e assegurar um certo fracionamento existente no mercado, permitindo às empresas ou setores da indústria coleções exclusivas que atendam, entre outros, o item "personalização" do produto. Desta forma, a "personalização" só pode ser obtida no interior da categoria mais geral e abstrata da "coleção exclusiva". É perceptível que a estratégia descrita refere-se à padronização de produtos para consumo massificado.

Esta seria a descrição mais objetiva que poderíamos oferecer através do exame da linguagem criada pelos estilistas, do processo que se costuma designar "democratização da moda", cuja análise pormenorizada deveria demonstrar que o produto pressupõe o consumidor.

Este é o problema que precisaria ser formulado de forma mais precisa para orientar a pesquisa sobre moda na 
atualidade. Este "prático guia-de-moda" é obra importante para acompanharmos na prática da indústria de roupas, a formulação de estratégias cujas noções parecem informar o debate acadêmico.

WHITE, Palmer. Poiret: o destino de um grande costureiro. São Paulo: Globo, 1990, 276p. (FAM) Paul Poiret (1879-1944) é apresentado como artista versátil, costureiro de fama internacional, personagem revolucionária da estética e dos costumes e criador da moda feminina do século XX, numa biografia laudatória, que contém ainda um prefácio composto em tom de depoimento pessoal do seu amigo e pintor Dunoyer de Segonzac. Obra pouco analítica mas bastante informativa sobre a vida do costureiro francês.

WILSON, Elisabeth. Enfeitada de sonbos: moda e modernidade.Tradução por Maria João Freire.

Lisboa: Edições 70, 1989, 342p. (FAM)

A proposta da A. é analisar a moda como "meio estético de expressão de idéias, desejos e crenças que circulam na sociedade". Neste sentido, a moda seria uma arte visual e, como tal, poderia constituir uma ideologia, uma solução imaginária de contradições sociais, segundo a definição de Frederic Jameson utilizada no texto. Na origem do fenômeno moda estaria, assim, constitutivamente, uma contradição: ela propõe-se como uma mudança distintiva mas generaliza-se até a uniformidade negando-se a si própria. Conceber a moda como ideologia não seria, no entanto, apontar para suas limitações mas explorar sua riqueza, o que a torna uma estratégia para a análise social. Na sua dimensão ideológica a moda seria uma "afirmação da falta de naturalidade dos empreendimentos sociais humanos", ou seja, apontaria para a historicidade dos fenônemos sociais, fato que exigiria para seu estudo uma abordagem plural que a observasse em suas ambigüidades e evitasse as explicações simplistas que a história, a sociologia e a psicologia do vestuário e da moda têm fornecido, incluindo-se aí as abordagens feministas.

Abreviaturas utilizadas

ECA/USP ESALQ/USP

FAM FAU/USP

FD/USP

FE/USP FEA/USP

FIL/USP

FSM HIS/USP

IEB/USP

LET/USP

MAC/USP

MP/USP

MRep

SENAC
Escola de Comunicações e Artes/Universidade de São Paulo Escola Superior de Agricultura "Luiz de Queiroz/

Universidade de São Paulo

Faculdade Anhembi-Morumbi

Faculdade de Arquitetura e Urbanismo/Universidade de São Paulo

Faculdade de Direito/Universidade de São Paulo

Faculdade de Educação/Universidade de São Paulo

Faculdade de Economia, Administração e Contabilidade/

Universidade de São Paulo

Departamento de Filosofia/Faculdade de Filosofia, Letras e Ciências Humanas/Universidade de São Paulo

Faculdade Santa Marcelina

Departamento de História/Faculdade de Filosofia, Letras e

Ciências Humanas/Universidade de São Paulo

Instituto de Estudos Brasileiros/Universidade de São Paulo

Departamento de Letras/Faculdade de Filosofia, Letras e

Ciências Humanas/Universidade de São Paulo

Museu de Arte Contemporânea/Universidade de São Paulo

Museu Paulista/Universidade de São Paulo

Museu da República/Rio de Janeiro

Serviço Nacional de Aprendizagem Comercial/ Centro de Moda e Decoração 
The shaping of ecomuseums: elements for analysis and understanding

Heloisa Barbury

This article seeks to trace an overall history of ecomuseums - especially in France - and to detect its roots in folkloristic as well as regional ethnography movements, from the end of the 19th-century until now. Aspects usually underrated are emphasized, as the role of collections and cultural heritage and the museographic patterns.

Uniterms: Ecomuseum. Histoy of the ecomuseum. Museology. Museography. Folklore Museum.

Anais do Museu Paulista, n.sér. v.3, p.209-236, 1995.

F. Braudel: tempo histórico e civilização material. Um ensaio bibliográfico

Antonio Penalves Rocha

A publicação recente da tradução brasileira da obra de Fernand Braudel, Civilisation matérielle et capitalisme, oferece uma boa oportunidade para o reexame de alguns aspectos deste livro. 0 presente ensaio pretende destacar a importância dada por Braudel às questões teóricas - principalmente sua concepção de tempo histórico e seu esforço para criar a unidade das ciências do homem - e o papel que desempenham na delimitação do objeto do livro.

Unitermos: Fernand Braudel. Tempo histórico. Civilização material

Anais do Museu Paulista, n.sér.v.3, p.239-249, 1995.

F.Braudel: historical time and material civilization. A bibliographical essay.

Penalves Rocha

The recent appearance of a Brasilian translation of Fernand Braudel's Civilisation matérielle et capitalisme is a good opportunity to reexamine some aspects of this seminal book and to seek to bound its central object. Special attention is called to the importance assigned by Braudel to some theoretical issues, under the aegis of "material civilization", mainly his concept of historical time and his effort to unify the social sciences.

Uniterms: Fernand Braudel. Historical time. Material civilization.

Anais do Museu Paulista, n.sér. v.3, p.239-249, 1995

Indumentária e moda: uma seleção bibliográfica em Português

Adilson José de Almeida

Foram descritivamente listados livros e capítulos de livros, traduzidos ou originalmente escritos em português, entre 1979 e 1996 e referentes a vários aspectos da indumentária e da moda. O objetivo é fornecer um quadro de referência de acesso imediato tanto para o especialista, como para o leigo. A lista propriamente dita está precedida por uma caracterização geral da bibliografia e por um tratamento mais demorado daqueles autores que se considerou representarem algumas importantes vertentes neste domínio.

Unitermos: Indumentária. Moda. Bibliografia seletiva e descritiva.

Anais do Muscu Paulista, n.sér. v.3, p.251-296, 1995.

Clothes and fashion: a select bibliography in Portuguese

Adilson José de Almeida

Books and book chapters, originally witten in Portuguese or translated into it, fom 1979 to 1996 , and related to several aspects of clothes, clothing and fashion are listed in order to provide an easily available frame of references for specialists as well as for laymen. The listing is preceded by a brief characterization of the bibliography and by a more detailed treatment of those authors considered to represent some impotant streams in this field.

Uniterms: Clothes. Fashion. Select descriptive bibliography Anais do Museu Paulista, n.sér. v.3, p.251-296, 1995 